\title{
Main objectives underlying mathematical model of powered support unit operation in terms of its working capacity
}

\begin{abstract}
This study synthesizes the operating data of a longwall system to determine the impacts of time, compressive strength of roof rock strata, rate of face advance, and distance between the cross bar in a roof support from the side wall on the value of the actual working capacity of powered supports. The analyses of the general linear models are supported by the Statistica program. Criteria imposed on the input data lead to the development of models of the powered support unit (shield) operation yielding corrected value of the coefficient R2(0,11-0,42), rendering the models statistically significant. For the investigated longwall panel, the minimal bearing capacity of the powered support obtained by several methods is compared with the actual bearing capacity of the powered support units. Mathematical models were recalled to obtain the pressure value that can be used in the further procedure as:

- pressure in a shield leg required to obtain the load-bearing capacity of a hydraulic leg in response to the load applied to the powered support,

- pressure exerted by rock strata on the longwall excavation, which is utilized to determine the real load acting on the powered support unit.
\end{abstract}

In the context of these two objectives, the roof stability factor was obtained accordingly, revealing excellent support-strata interactions under the specified geological and mining conditions.

Key words: operating pressure, bearing capacity, longwall mining method, rock mass pressure

\section{INTRODUCTION}

The longwall mining system is one of the mostpopular methods of coal extraction world-wide. When compared to the second-best mining method (the room and pillar system), it offers higher productivity; however, the mining machinery and equipment are very costly. The mining machinery and equipment referred to as the longwall system include a shearer (or the coal plow head and its drives), a face conveyor, a drag conveyor, powered supports, an instrumentation truck, and a hydraulic power-supply system. Selecting the longwall system components such that they operate and interact smoothly under the specified geological and mining conditions should guarantee the uninterrupted mining operations and pre-determined output levels $[1,2]$. The fundamental criteria in the selection of mining machines include the extraction height (height of the coal seam) as well as the longitudinal and lateral inclination of the longwall site. When the longwall system components have been originally designed to interact, checking this aspect of their performance is not necessary. However, when the machines and longwall equipment are provided by several manufacturers or include components from different mining systems (even if they are provided by one manufacturer), the actual feasibility of machine interactions has to be first ascertained. 
In the next step, the production capacity of the coal mining machine and hauling capacity of the face conveyor are checked in the context of ensuring the daily output levels. As regards the powered supports, of particular importance are the technical conditions and shield-strata interactions ensuring roof stability over the working site in the longwall excavation $[3,4$, $5,6,7,8-10]$. To ensure adequate shield-roof strata interactions, the initial and working capacity of the powered support need to be appropriate $[4,11,12]$. Time-variant working capacity is the response to loading imposed on a powered support by roof strata. Load components contributing the total shield loading include the following $[3,6,13,14]$ :

- rock mass pressure associated with the extraction depth, presence of old excavations, and dip of the coal seam;

- the range of the longwall excavations understood as the distance between the longwall face and caved-in section;

- shield standstill time.

Selecting the powered-support systems and adapting them to the geological and mining conditions does not always guarantee the correct shield-strata interactions. In order that the initial bearing capacity should be uniform and set, the shield legs are equipped with control systems incorporating a secondary pressure-charging system. However, in weak roof zones where a shield has a too-high set pressure (which may contribute to the poorer roof condition), the pressure-charging system is frequently switched off by the operators $[12,15,16]$. Its absence leads to non-uniform leg pressure and, in certain cases, to the inadequate clamping of the shield against the roof, which as a consequence results in roof and wall sliding, the caving-in of the roof rocks, and overloading the powered support units.

\section{METHODS OF PARAMETER SELECTION AND TESTING SHIELD-STRATA INTERACTIONS}

Most Polish collieries rely on the admissible roof deformation method when assessing the adequacy of shield-roof strata interactions [6, 13, 14].

The condition for adequate roof support is satisfied as long as the value of roof-stability factor $g$ is at least 0.8 . It is a critical level; when $g$ is less than 0.8 , there is a risk of roof rock sliding and the deterioration of roof conditions. It is a widely accepted view that, for $0.7=g<0.8$, there is a risk of roof control problems at longwall sites. These difficulties are associated with the risk of roof strata sliding and the vertical displacement of rock strata [5].

Roof stability factor $g$ is derived from the following formula [6]:

$$
g=\frac{1}{\frac{0.65 \cdot z_{1}}{z_{g}}+0.3}
$$

where:

$z_{1}-$ unit roof inclination,

$z_{g}-$ critical roof inclination.

Exceeding the critical subsidence value may result in the unravelling of the rock strata. The critical value of the subsidence varies depending on the rock type. Observations at longwall sites have allowed us to find the critical inclination of the roof composed of specific rocks. When exceeded, the roof becomes a loose conglomerate of rock fragments. This quantity is expressed as roof inclination $z_{g}$ in millimeters per $1 \mathrm{~m}$ of roof span [5]:

$$
z_{g}=\frac{k_{e}}{\frac{0.05}{R_{c s}}+0.006}\left[\frac{\mathrm{mm}}{\mathrm{m}}\right]
$$

where:

$k_{e}$ - coefficient related to the adopted mining system (0.8 - for caving-in; 0.35 - for hydraulic back-filling),

$R_{c s}$ - compressive strength of roof strata [MPa].

Unit roof inclination $z_{1}[\mathrm{~mm} / \mathrm{m}]$, or the roof inclination over the first meter of the excavation range from the longwall face, is the major determinant of roof subsidence over the entire longwall site.

In the case of longwall mining with caving-in, $z_{1}$ is derived from the following formula [6]:

$$
z_{1}=\frac{1}{0.013 m_{p}+0.002}\left[\frac{\mathrm{mm}}{\mathrm{m}}\right]
$$

where $m_{p}$ is the ratio of shield-bearing capacity moment $M_{p}[\mathrm{MN} \cdot \mathrm{m}]$ to the moment of the load acting on the excavation $M_{Q}[\mathrm{MN} \cdot \mathrm{m}]$. 
To determine the unit roof inclination, it is required that resultant bearing capacity moment $M_{p}$ and the average bearing capacity of powered support $P_{z}$ should first be calculated (Formula (4)). The average bearing capacity is determined for the face section in which one powered support is set against the roof with the initial bearing capacity, the second powered support is displaced towards the side wall, while the next support unit has not yet been moved. These are the least-favorable conditions experienced during the normal duty cycle of the powered support operation [6]:

$$
\begin{aligned}
& P_{z}=\frac{i \cdot n_{k} \cdot n_{w} \cdot P_{r}}{3 b} \cdot \\
& {\left[\frac{\left(1-n_{0}\right) \cdot\left(d_{02}-d_{01}\right)}{\frac{100 \cdot e^{-3.5 \cdot e^{-8 n_{c z}}}}{z_{s} r}+\left(1+e^{-1.8 \cdot e^{-2 \cdot n_{c z}}}\right)}+2 \cdot n_{m} \cdot n_{0}\right][\mathrm{MN}]}
\end{aligned}
$$

where:

$i$ - number of hydraulic legs in the shields,

$n_{k}$ - leg capacity reduction factor,

$n_{w}$ - factor expressing the bearing capacity transferred from the shield onto the roof,

$P_{r}$ - working capacity of shield legs [MN],

$n_{o}-$ initial to working capacity ratio,

$$
n_{o}=\frac{P_{w}}{P_{r}}
$$

$P_{w}-$ initial capacity of shield legs [MN],

$d_{02}-d_{01}-$ initial and final distance of the considered segment of the working to the face,

$n_{c z}-$ shield performance factor,

$z_{s r}$ - average convergence of the longwall working over the distance $d_{01}-d_{02}$,

$n_{m}$ - factor expressing the impacts of low bearing capacity of surrounding strata.

Moment of shield bearing capacity is expressed as follows [6]:

$$
M_{p}=P_{z} \cdot l_{z} \quad[\mathrm{MN} \cdot \mathrm{m}]
$$

where $l_{z}$ is the arm length of load-bearing force $P_{z}$.

The weight of the rock strata on the longwall site is equal to the weight of a rock mass solid section one meter in width counted alongside the face; its base length normal to the face line and equal to the extent of the longwall excavation. The height of the solid section and the actual shape of side walls are dependent on the adopted extraction method and roof strength.

The load per running meter of the longwall excavation for the longwall mining system with cave-in is expressed as follows [6]:

$$
Q=n_{q} \cdot n_{a} \cdot h_{s} \cdot c_{w} \frac{L_{i}^{1.4}}{0.13 \cdot R_{c}^{0.5}+0.7} \quad[\mathrm{MN}]
$$

where:

$$
\begin{aligned}
& n_{a}-\text { load rate factor, } \\
& n_{g}-\text { de-stressed strata range factor, } \\
& c_{w}-\text { bulk density of roof rock }\left[\mathrm{NM} / \mathrm{m}^{3}\right], \\
& h_{s}-\text { reduced height of the longwall working }[\mathrm{m}], \\
& L_{i}-\text { longwall site span }[\mathrm{m}], \\
& R_{c}-\text { compressive strength of roof strata }[\mathrm{MPa}] .
\end{aligned}
$$

The loading moment acting on the longwall excavation is given as follows [6]:

$$
M_{Q}=0.7 \cdot L_{i} \cdot Q \quad[\mathrm{MN} \cdot \mathrm{m}]
$$

The minimal working capacity of a powered support can be derived from the following formula:

$$
P=\frac{Q}{0.7}(g-0.3) \quad[\mathrm{MN}]
$$

To guarantee good roof stability, the value of $g$ should be equal to or greater than 0.8 .

In countries with a well-established extractive sector and extensive mining expertise, methods have been developed to support the selection of shield capacity.

For example, in Great Britain [17], the minimal bearing capacity of a powered support is derived from the following formula:

$$
P \geq \frac{m}{k-1} \cdot \gamma\left[\frac{\mathrm{Mg}}{\mathrm{m}^{2}}\right]
$$

The minimal bearing capacity of powered supports under the geological and mining conditions outlined in Section 3 has been calculated by the presented methods. These results are summarized in Table 1. 
Table 1

Minimal shield capacity obtained by selected methods

\begin{tabular}{|c|l|c|}
\hline Lp. & \multicolumn{1}{|c|}{ Method } & $\begin{array}{c}\text { Minimal shield } \\
\text { capacity } \\
\boldsymbol{P}_{\text {min }}\left[\mathbf{k N} / \mathbf{m}^{2}\right]\end{array}$ \\
\hline 1 & Poland [17] & 200 \\
\hline 3 & Great Britain [17] & 267 \\
\hline 4 & Germany [17] & 214 \\
\hline 5 & Terzaghi [11] & 128 \\
\hline 6 & Yehia [18] & 95 \\
\hline
\end{tabular}

\section{GEOLOGICAL AND MINING CONDITIONS}

The panel considered in this study was nearly horizontal, the longitudinal inclination angle of the opening-up cross-cut was $2^{\circ}$, and the seam thickness varied from $1.33 \mathrm{~m}$ to $1.8 \mathrm{~m}$ (with the average value being $1.6 \mathrm{~m}$ ). The compressive strength of the coal beds fell to within a range of 12-18 MPa. The longwall face to be operated upon was $250 \mathrm{~m}$ in length with a 1750 -meter range.

The immediate roof in the area was comprised of claystone, mudstone, and sandstone strata. The thickness of the claystone directly above the coal seam ranged from $0.8 \mathrm{~m}$ to $2.0 \mathrm{~m}$, revealing the local occurrence of spherical siderite features. Directly overlying the claystone was the mudstone bed; its thickness ranging from $0.2 \mathrm{~m}$ to more than $7 \mathrm{~m}$. The mudstone layer was the thickest in the central part of the face range. Overlying the mudstone was a sandstone bed of up to $7 \mathrm{~m}$ in thickness (also revealing mudstone interlayers). The sandstone bed was the thickest in the front sections of the face range. Overlying the sandstone bed were alternating layers of claystone, mudstone, and coal. The geomechanical test data yielded a contour map of compressive strength distribution $R_{c}$ of the roof strata overlying the longwall panel (Fig. 1).
In the floor strata alongside the face range, there was a claystone bed of between $0.3 \mathrm{~m}$ to $1.5 \mathrm{~m}$ in thickness. Underneath are the alternating mudstone, stigmaria mudstone, sandstone, and claystone strata with coal inclusions, revealing the presence of numerous spherical siderite features (particularly in the mudstone). No faulting or seismic discontinuities were observed in the area. The operated automated plow system incorporated the following components:

- Gliding plow GH 1600 operating at $0.98-2.2 \mathrm{~m}$ seam height. The longwall operations use the version with the lowest plow body height (980-1230 m).

- Face conveyor PF-1032 with a front discharge chute.

- Gate-end conveyor PF-1132.

- One hundred and forty-one powered support units. From the gateway end, there are 3 units in the opening section, a linear array of 134 units, and 4 units from the ancillary drive end.

The technical parameters of the powered support sections are summarized in Table 2.

Table 2

Operating parameters of powered support (shield) sections

\begin{tabular}{|l|l|c|c|}
\hline \multicolumn{2}{|c|}{ Parameter } & Value & Unit \\
\hline \multicolumn{2}{|l|}{ Shield height range } & $0.95-2.0$ & {$[\mathrm{~m}]$} \\
\hline Operating range & $1.0-1.9$ & {$[\mathrm{~m}]$} \\
\hline $\begin{array}{l}\text { Admissible } \\
\text { inclination }\end{array}$ & longitudinal & to $15^{\circ}$ & {$[-]$} \\
\cline { 2 - 4 } & lateral & $\pm 15^{\circ}$ & {$[-]$} \\
\hline Pitch & 1.75 & {$[\mathrm{~m}]$} \\
\hline Step & to 0.85 & {$[\mathrm{~m}]$} \\
\hline Number of legs & 2 & {$[\mathrm{pieces}]$} \\
\hline Leg diameter & $\varnothing 320$ & {$[\mathrm{~mm}]$} \\
\hline $\begin{array}{l}\text { Bearing capacity } \\
\text { of the leg }\end{array}$ & initial (32 MPa) & 2573 & {$[\mathrm{MN}]$} \\
\cline { 2 - 4 } & operating (45 MPa) & 3619 & {$[\mathrm{MN}]$} \\
\hline Cross bar length & 4030 & {$[\mathrm{~mm}]$} \\
\hline Operating pressure & 45 & {$[\mathrm{MPa}]$} \\
\hline Supply pressure & 32 & {$[\mathrm{MPa}]$} \\
\hline
\end{tabular}

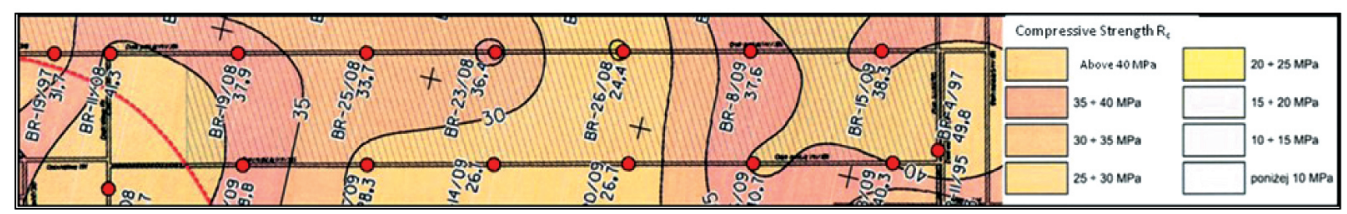

Fig 1. Compressive strength Rc of roof strata up to $6 \mathrm{~m}$ above coal seam roof (derived by A. Ruchel) 


\section{DATA ANALYSIS FROM V-SHIELD PROGRAM}

In the considered longwall site roof, support is provided by 141 powered support units. State-of-the-art equipment enables the effective monitoring and visualization of the shield operation as well as control of the remaining machinery within the longwall system. Key parameters obtained from the visualization system include the following $[2,18,20,21]$ :

- $p$ - pressure in the space beneath the piston in the shield leg, [MPa],

$-w-$ length of the divider cylinder in its forth position $[\mathrm{m}]$,

$-v$ - rate of face advance [m/day],

$-t_{p}-$ shield standstill time [min].

The analyses rely on roof baring parameter $d \mathrm{~m}$, understood as the distance between the cross-bar end (counting from the face front) and the face, substituted for the length of the divider cylinder in its forth position. Distance $d$ is the component of distance $L_{t}$ between the cross-beam end and the longwall face (resulting from the actual configuration of the longwall system prior to the cut) and web of coal $z$. For the longwall system considered in this study, distance $L_{t}$ is $0.5 \mathrm{~m}$, and the maximal web of coal is taken to be $0.7 \mathrm{~m}$. Maximal roof baring value $\mathrm{d}$ should be $1.2 \mathrm{~m}$ (though it in fact approached $1.4 \mathrm{~m}$ ).

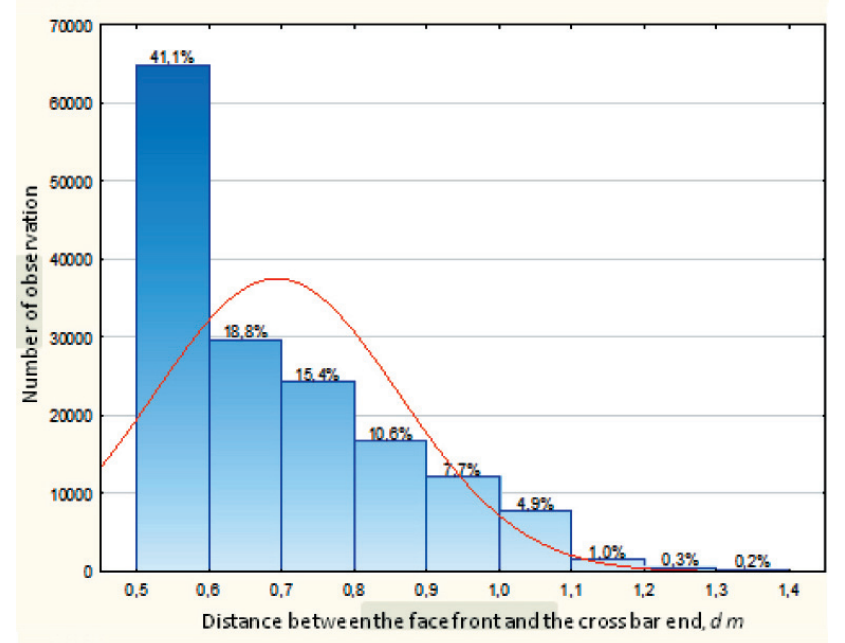

Fig. 2. Roof baring distribution [d]
Based on the results summarized in $[2,18,20]$, for the analyses used:

- powered support units from 30 to 100;

- maximal standstill time $t_{p}$ below $250 \mathrm{~min}$; within this time period, the shield operates within the working pressure range;

- maximal pressure level $42 \mathrm{MPa}$;

- minimal pressure level $24 \mathrm{MPa}$.

It appears that $41 \%$ of the roof baring values fall within a range of $0.5 \mathrm{~m}$ to $0.6 \mathrm{~m}$ (see Fig. 2). Roof baring rates within a range of $0.6 \mathrm{~m}$ to $0.9 \mathrm{~m}$ follow a similar pattern (44.8\%). The remaining interval of roof baring values from the nominal coal web of $1.2 \mathrm{~m}$ accounts for $13.6 \%$ of the cases. In only $0.5 \%$ of the cases, the actual value of $d$ should exceed $1.2 \mathrm{~m}$. Figure 3 illustrates leg pressure distribution $p$. It appears that, for the pressure increment of $8 \mathrm{MPa}$ (from $24 \mathrm{MPa}$ to $32 \mathrm{MPa}$ ), we get $57 \%$ of the pressure readings; the remaining $43 \%$ are registered following a further pressure increase by $10 \mathrm{MPa}$ (from $32 \mathrm{MPa}$ to $42 \mathrm{MPa}$ ). Dominating rates of face advance accounting for $34 \%$ of the registered values are those within a range of 10-12 m daily (Fig. 4). The shield standstill time $t_{p}$ distribution follows a similar pattern (Fig. 5). It appears that, 38\% of the registered standstill times are below $10 \mathrm{~min}, 60 \%$ of the registered standstill times coincide with time required to complete the full web of coal $(z=0.7 \mathrm{~m})$, which is equal to $27 \mathrm{~min}$. The remaining $40 \%$ of the registered standstill time values are associated with roof baring in excess of $1.2 \mathrm{~m}$.

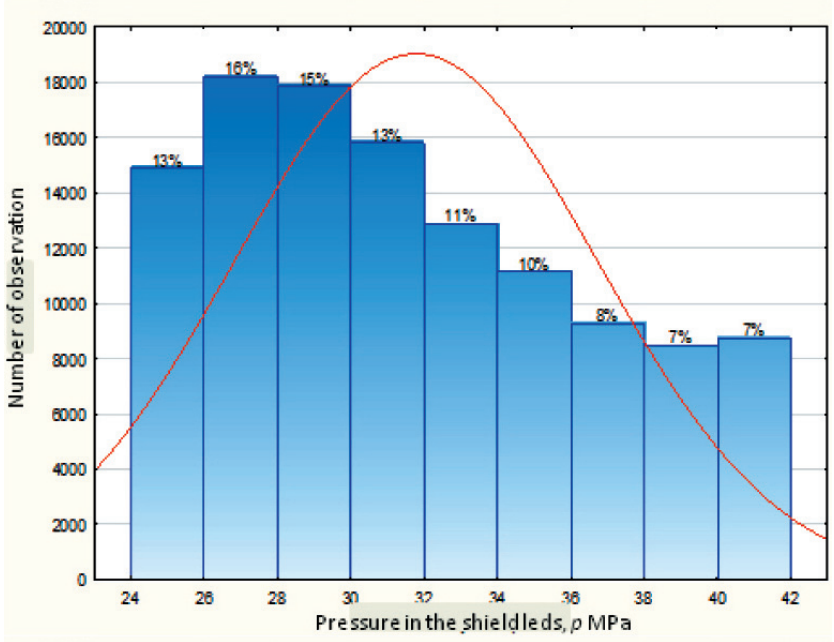

Fig. 3. Distribution of shield leg pressure [p] 


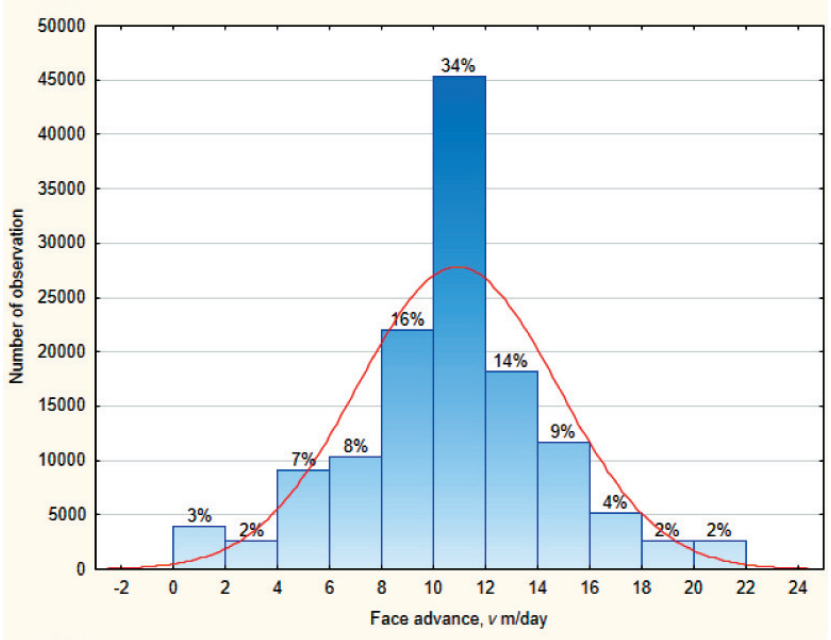

Fig. 4. Distribution of rate of face advance [v]

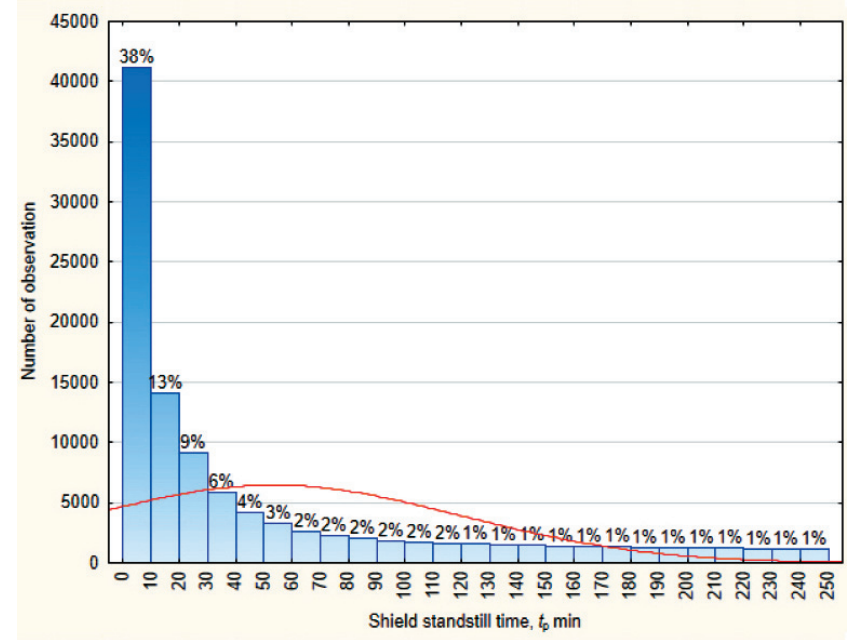

Fig. 5. Shield standstill time [tp]

\section{MULTI-PARAMETRIC MODEL OF THE SHIELD OPERATION}

The model of the shield performance is based on a linear model that is widely employed in analyses of ANOVA or MANOVA systems incorporating categorized predictors, any ANOVA or MANOVA systems incorporating both categorized and continuous variables, and multiple and multi-dimensional regression models involving continuous independent variables. The model encapsulates two methods of data coding and analysis; interpretation of the measurement data is supported by a model with sigma constraints adapted by Statistica (qualitative predictor coding), which can handle two arbitrary yet different values of single dependent variables (predictors). Thus, the obtained values of the independent variable will represent the group membership in quantitative terms. Typically, the values corresponding to group membership are not selected at random but in a manner supporting the interpretation of the regression coefficient value related to the dependent variable (predictor). In one of the strategies in widespread use, events from two groups are ascribed values of dependent variables equal to 1 and -1 ; therefore, when the regression coefficient for the given variable is positive, the predicted value of the group encoded in the independent variable as 1 shall be higher (a higher group mean value). When the coefficient of regression is negative, the group encoded in the independent vari- able as -1 shall produce a higher predicted value of the dependent variable. Another advantage of this approach is that each group is encoded by a value different from zero by one, which makes easier the interpretation of the predicted differences between groups as coefficients of the regression yield; a unit variation of the dependent variable for each unit variation of the independent variable (predictor). This coding strategy is referred to as a parameterization with sigma constraints, because the sets of parameters indicating group membership $(1$ and -1$)$ sum to zero [22].

Several variants have been considered in the calculation procedure, subdividing the standstill times and roof baring rates in various configurations. The values of the statistical indicators are optimal for the following configuration of operational parameters (Tab. 3):

- standstill time within a range of $0 \mathrm{~min}$ to $250 \mathrm{~min}$; - roof baring process subdivided into intervals:

- $0.5 \mathrm{~m} \leq d<0.6 \mathrm{~m}$,

- $0.6 \mathrm{~m} \leq d<0.9 \mathrm{~m}$,

- $0.9 \mathrm{~m} \leq d<1.2 \mathrm{~m}$,

- $1.2 \mathrm{~m} \leq d<1.4 \mathrm{~m}$.

For barred roof area intervals $0.5 \mathrm{~m} \leq d<0.6 \mathrm{~m}$ and $1.2 \mathrm{~m} \leq d<1.4 \mathrm{~m}$, the rate of face advance is found to be statistically insignificant.

The analysis of the full models revealed their statistical significance, and the corrected value of coefficient $\mathrm{R}^{2}$ is regarded as satisfactory (Table 4). 
Table 3

Statistical significance of model parameters

\begin{tabular}{|c|c|c|c|c|c|c|c|c|c|c|}
\hline Effect & $\begin{array}{c}\text { Leg } \\
\text { pres- } \\
\text { sure, } \\
p \text { [MPa] }\end{array}$ & $\begin{array}{c}\text { Leg } \\
\text { pres- } \\
\text { sure, } \\
p \text { [MPa] }\end{array}$ & $\begin{array}{c}\text { Leg } \\
\text { pres- } \\
\text { sure, } \\
p \text { [MPa] }\end{array}$ & $\begin{array}{c}\text { Leg } \\
\text { pres- } \\
\text { sure, } \\
p \text { [MPa] }\end{array}$ & $\begin{array}{c}-95.00 \\
{[\%]}\end{array}$ & $\begin{array}{l}+95.00 \\
{[\% \%]}\end{array}$ & $\begin{array}{c}\text { Leg } \\
\text { pres- } \\
\text { sure, } \\
p \text { [MPa] }\end{array}$ & $\begin{array}{c}\text { Leg } \\
\text { pres- } \\
\text { sure, } \\
p \text { [MPa] }\end{array}$ & $\begin{array}{c}-95.00 \\
{[\%]}\end{array}$ & $\begin{array}{l}+95.00 \\
{[\%]}\end{array}$ \\
\hline \multicolumn{11}{|c|}{$\begin{array}{l}\text { Parameter evaluation: sigma parameterization with constraints } \\
\text { Acceptance condition: } d \geq 0,5 \mathrm{~m} ; d<0,6 \mathrm{~m} ; p \geq 24 \mathrm{MPa} ; p \leq 42 \mathrm{MPa} ; t_{p} \leq 250 \mathrm{~min}\end{array}$} \\
\hline Free term & 42.271 & 0.471 & 89.661 & 0.000 & 41.347 & 43.195 & & & & \\
\hline Roof barring factor & -20.618 & 0.792 & -26.043 & 0.000 & -22.170 & -19.066 & -0.118 & 0.005 & -0.127 & -0.109 \\
\hline $\begin{array}{l}\text { Rate of face } \\
\text { advance factor }\end{array}$ & -0.010 & 0.005 & -1.888 & 0.059 & -0.020 & 0.000 & -0.009 & 0.005 & -0.018 & 0.000 \\
\hline $\begin{array}{l}\text { Compressive } \\
\text { strength of roof } \\
\text { strata factor }\end{array}$ & -0.095 & 0.005 & -17.914 & 0.000 & -0.105 & -0.084 & -0.081 & 0.005 & -0.090 & -0.072 \\
\hline $\begin{array}{l}\text { Standstill time } \\
\text { of a support unit } \\
\text { factor }\end{array}$ & 0.037 & 0.000 & 132.103 & 0.000 & 0.036 & 0.037 & 0.621 & 0.005 & 0.611 & 0.630 \\
\hline \multicolumn{11}{|c|}{ Acceptance condition: $d \geq 0.6 \mathrm{~m} ; d<0.9 \mathrm{~m} ; p \geq 24 \mathrm{MPa} ; p \leq 42 \mathrm{MPa} ; t_{p} \leq 250 \mathrm{~min}$} \\
\hline Free term & 25.763 & 0.190 & 135.863 & 0.000 & 25.391 & 26.134 & & & & \\
\hline Roof barring factor & 8.577 & 0.183 & 46.769 & 0.000 & 8.217 & 8.936 & 0.176 & 0.004 & 0.168 & 0.183 \\
\hline $\begin{array}{l}\text { Rate of face } \\
\text { advance factor }\end{array}$ & -0.032 & 0.004 & -7.286 & 0.000 & -0.041 & -0.024 & -0.028 & 0.004 & -0.035 & -0.020 \\
\hline $\begin{array}{l}\text { Compressive } \\
\text { strength of roof } \\
\text { strata factor }\end{array}$ & -0.098 & 0.004 & -24.839 & 0.000 & -0.106 & -0.090 & -0.093 & 0.004 & -0.101 & -0.086 \\
\hline $\begin{array}{l}\text { Standstill time } \\
\text { of a support unit } \\
\text { factor }\end{array}$ & 0.038 & 0.000 & 138.473 & 0.000 & 0.037 & 0.038 & 0.528 & 0.004 & 0.521 & 0.536 \\
\hline \multicolumn{11}{|c|}{ Acceptance condition: $d \geq 0.9 \mathrm{~m} ; d<1.2 \mathrm{~m} ; p \geq 24 \mathrm{MPa} ; p \leq 42 \mathrm{MPa} ; t_{p} \leq 250 \mathrm{~min}$} \\
\hline Free term & 28.286 & 0.546 & 51.834 & 0.000 & 27.216 & 29.355 & & & & \\
\hline Roof barring factor & 7.417 & 0.477 & 15.555 & 0.000 & 6.483 & 8.352 & 0.112 & 0.007 & 0.098 & 0.126 \\
\hline $\begin{array}{l}\text { Rate of face } \\
\text { advance factor }\end{array}$ & 0.086 & 0.009 & 9.336 & 0.000 & 0.068 & 0.104 & 0.068 & 0.007 & 0.054 & 0.083 \\
\hline $\begin{array}{l}\text { Compressive } \\
\text { strength of roof } \\
\text { strata factor }\end{array}$ & -0.159 & 0.008 & -20.954 & 0.000 & -0.174 & -0.144 & -0.152 & 0.007 & -0.166 & -0.138 \\
\hline $\begin{array}{l}\text { Standstill time } \\
\text { of a support unit } \\
\text { factor }\end{array}$ & 0.030 & 0.001 & 41.595 & 0.000 & 0.028 & 0.031 & 0.303 & 0.007 & 0.289 & 0.317 \\
\hline \multicolumn{11}{|c|}{ Acceptance condition: $d \geq 1.2 \mathrm{~m} ; d<1.4 \mathrm{~m} ; p \geq 24 \mathrm{MPa} ; p \leq 42 \mathrm{MPa} ; t_{p} \leq 250 \mathrm{~min}$} \\
\hline Free term & 28.459 & 4.737 & 6.008 & 0.000 & 19.156 & 37.763 & & & & \\
\hline Roof barring factor & 9.302 & 3.671 & 2.534 & 0.012 & 2.092 & 16.512 & 0.100 & 0.039 & 0.022 & 0.177 \\
\hline $\begin{array}{l}\text { Rate of face } \\
\text { advance factor }\end{array}$ & 0.075 & 0.048 & 1.589 & 0.113 & -0.018 & 0.169 & 0.062 & 0.039 & -0.015 & 0.140 \\
\hline $\begin{array}{l}\text { Compressive } \\
\text { strength of roof } \\
\text { strata factor }\end{array}$ & -0.236 & 0.038 & -6.139 & 0.000 & -0.311 & -0.160 & -0.243 & 0.040 & -0.320 & -0.165 \\
\hline $\begin{array}{l}\text { Standstill time } \\
\text { of a support unit } \\
\text { factor }\end{array}$ & 0.030 & 0.005 & 5.672 & 0.000 & 0.019 & 0.040 & 0.221 & 0.039 & 0.145 & 0.298 \\
\hline
\end{tabular}


Table 4

Statistical significance of models

\begin{tabular}{|c|c|c|c|c|c|c|c|c|c|c|c|}
\hline $\begin{array}{l}\text { Depend. } \\
\text { variable }\end{array}$ & $\underset{R}{\text { Multiple }}$ & $\underset{R^{2}}{\text { Multiple }}$ & $\begin{array}{l}\text { Corrected } \\
R^{2}\end{array}$ & $\begin{array}{l}\text { SS } \\
\text { Model }\end{array}$ & $\begin{array}{c}\text { df } \\
\text { Model }\end{array}$ & $\begin{array}{c}\text { MS } \\
\text { Model }\end{array}$ & $\begin{array}{c}\text { SS } \\
\text { Model }\end{array}$ & $\begin{array}{l}\text { Df } \\
\text { Model }\end{array}$ & $\begin{array}{l}\text { MS } \\
\text { Model }\end{array}$ & $\boldsymbol{F}$ & $p$ \\
\hline \multirow{8}{*}{ 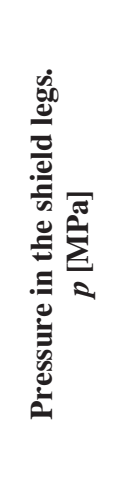 } & \multicolumn{11}{|c|}{$\begin{array}{c}\text { SS Test for the full model with respect to SS for the residues } \\
\text { Acceptance condition: } d \geq 0.5 \mathrm{~m} ; d<0.6 \mathrm{~m} ; p \geq 24 \mathrm{MPa} ; p \leq 42 \mathrm{MPa} ; t_{p} \leq 250 \mathrm{~min}\end{array}$} \\
\hline & 0.65 & 0.42 & 0.42 & 242836.6 & 4.0 & 60709.1 & 331315.4 & 28241.0 & 11.73 & 5174.8 & 0.0 \\
\hline & \multicolumn{11}{|c|}{ Acceptance condition: $d \geq 0.6 \mathrm{~m} ; d<0.9 \mathrm{~m} ; p \geq 24 \mathrm{MPa} ; p \leq 42 \mathrm{MPa} ; t_{p} \leq 250 \mathrm{~min}$} \\
\hline & 0.57 & 0.32 & 0.32 & 271432.8 & 4.0 & 67858.2 & 575853.8 & 48471.0 & 11.88 & 5711.8 & 0.0 \\
\hline & \multicolumn{11}{|c|}{ Acceptance condition: $d \geq 0.9 \mathrm{~m} ; d<1.2 \mathrm{~m} ; p \geq 24 \mathrm{MPa} ; p \leq 42 \mathrm{MPa} ; t_{p} \leq 250 \mathrm{~min}$} \\
\hline & 0.36 & 0.13 & 0.13 & 41575.2 & 4.0 & 10393.8 & 283845.8 & 16852.0 & 16.84 & 617.1 & 0.0 \\
\hline & \multicolumn{11}{|c|}{ Acceptance condition: $d \geq 1.2 \mathrm{~m} ; d<1.4 \mathrm{~m} ; p \geq 24 \mathrm{MPa} ; p \leq 42 \mathrm{MPa} ; t_{p} \leq 250 \mathrm{~min}$} \\
\hline & 0.34 & 0.12 & 0.11 & 1330.1 & 4.0 & 332.5 & 9909.4 & 582.0 & 17.03 & 19.5 & 0.0 \\
\hline
\end{tabular}

For each analytical procedure, the mathematical model of shield operation is determined accordingly:

The first interval of barred roof area $0.5 \mathrm{~m} \leq d<$ $0.6 \mathrm{~m}$ is governed by the following formula:

$$
\begin{array}{r}
p=42.2711-20.6182 \cdot d-0.0099 \cdot v \\
-0.0948 \cdot R_{c}+0.0369 \cdot t_{p} \quad[\mathrm{MPa}]
\end{array}
$$

The second interval $0.6 \mathrm{~m} \leq d<0.9 \mathrm{~m}$ is expressed by:

$$
\begin{aligned}
p & =25.7626+8.5766 \cdot d-0.0324 \cdot v \\
& -0.0982 \cdot R_{c}+0.0375 \cdot t_{p} \quad[\mathrm{MPa}]
\end{aligned}
$$

Third interval $0.9 \mathrm{~m} \leq d<1.2 \mathrm{~m}$ is governed by:

$$
\begin{array}{r}
p=28.2858+7.4174 \cdot d+0.0857 \cdot v \\
-0.159 \cdot R_{c}+0.0295 \cdot t_{p} \quad[\mathrm{MPa}]
\end{array}
$$

Fourth interval $1.2 \mathrm{~m} \leq d<1.4 \mathrm{~m}$ is expressed by:

$$
\begin{aligned}
p & =28.4591+9.3019 \cdot d+0.0755 \cdot v \\
& -0.2357 \cdot R_{c}+0.0296 \cdot t_{p} \quad[\mathrm{MPa}]
\end{aligned}
$$

\section{APPLICATION OF SHIELD OPERATION MODEL TO DETERMINE SHIELD-STRATA INTERACTIONS}

Thus, the obtained mathematical models of the shield operations can be used to determine working capacity $P_{r}$ (Tab. 5) and loading moment $M_{Q}$ of a pow- ered support as well as roof stability factor $g$. The predicted values of $p$ derived from Formulas (11)-(14) can be further used in two alternative procedures:

1. Assuming that the predicted value of $\mathrm{p}$ is the working capacity of a shield leg $P_{r}$ (Tab. 5, Column 6), the equivalent bearing capacity $P_{z}$ (Eq. (4)) and bearing capacity moment $M_{P}$ (Eq. (6)) can be obtained accordingly. Recalling Equations (7) and (8), we get the loading of the longwall site $Q$ and the loading moment $M_{Q}$. These are used to determine roof stability factor $g$ (Eq. (1)). It is readily apparent that the value of $g$ tends to increase with working capacity (Tab. 5, Column 6), indicating good shield-strata interactions. Such a favorable value of $g$ is attributed to the working capacity of a shield leg increasing over time and time-invariant loading of the longwall site.

2. Assuming that the obtained predicted value of $p$ expresses time-variant load $Q$ acting on the longwall excavation, Equation (8) can be recalled to derive loading moment $M_{Q}$ (Tab. 5, Column 7). The equivalent bearing capacity $P_{z}$ is determined for nominal values of working capacity $P_{r}$ and initial capacity $P_{w}$ of a powered support (Eq. (4)). Shield capacity moment $M_{p}$ is derived from Equation (6), and roof stability factor $g$ is obtained from Formula (1) (Tab. 5, Column 8). It appears that the values of $g$ are lower by half, which is attributed to the fixed value of working capacity $P_{r}$ while the load acting on the longwall site $Q$ tends to increase over time. Nevertheless, the obtained values of $g$ are still sufficient to guarantee adequate shield-strata interactions. In this particular case, the value of $g$ tends to decrease with increasing standstill time $t_{p}$. 
Table 5

Selected values of roof stability factor derived from mathematical models of shield operation

\begin{tabular}{|c|c|c|c|c|c|c|c|}
\hline$R_{c}[\mathrm{MPa}]$ & $d[\mathrm{~m}]$ & $v[\mathrm{~m} / \mathrm{day}]$ & $t_{p}[\mathrm{~min}]$ & $g$ & $P_{r}[\mathrm{MN}]$ & $M_{Q}[\mathbf{M N m}]$ & $g$ \\
\hline 1 & 2 & 3 & 4 & 5 & 6 & 7 & 8 \\
\hline \multirow{12}{*}{30} & \multirow{12}{*}{0.5} & 5 & \multirow{4}{*}{30} & 2.03 & 2.57 & 16.29 & 0.92 \\
\hline & & 10 & & 2.03 & 2.57 & 16.29 & 0.92 \\
\hline & & 15 & & 2.03 & 2.57 & 16.29 & 0.92 \\
\hline & & 20 & & 2.03 & 2.57 & 16.29 & 0.92 \\
\hline & & 5 & \multirow{4}{*}{60} & 2.03 & 2.57 & 16.29 & 0.92 \\
\hline & & 10 & & 2.03 & 2.57 & 16.29 & 0.92 \\
\hline & & 15 & & 2.03 & 2.57 & 16.29 & 0.92 \\
\hline & & 20 & & 2.03 & 2.57 & 16.29 & 0.92 \\
\hline & & 5 & \multirow{4}{*}{250} & 2.07 & 3.07 & 19.46 & 0.84 \\
\hline & & 10 & & 2.07 & 3.07 & 19.46 & 0.84 \\
\hline & & 15 & & 2.07 & 3.07 & 19.46 & 0.84 \\
\hline & & 20 & & 2.07 & 3.06 & 19.40 & 0.84 \\
\hline \multirow{12}{*}{30} & \multirow{12}{*}{0.8} & 5 & \multirow{4}{*}{30} & 2.00 & 2.57 & 17.37 & 0.95 \\
\hline & & 10 & & 2.00 & 2.57 & 17.37 & 0.95 \\
\hline & & 15 & & 2.00 & 2.57 & 17.37 & 0.95 \\
\hline & & 20 & & 2.00 & 2.57 & 17.37 & 0.95 \\
\hline & & 5 & \multirow{4}{*}{60} & 2.00 & 2.57 & 17.37 & 0.95 \\
\hline & & 10 & & 2.00 & 2.57 & 17.37 & 0.95 \\
\hline & & 15 & & 2.00 & 2.57 & 17.37 & 0.95 \\
\hline & & 20 & & 2.00 & 2.57 & 17.37 & 0.95 \\
\hline & & 5 & \multirow{4}{*}{250} & 2.05 & 3.12 & 21.09 & 0.85 \\
\hline & & 10 & & 2.05 & 3.11 & 21.02 & 0.85 \\
\hline & & 15 & & 2.05 & 3.10 & 20.96 & 0.85 \\
\hline & & 20 & & 2.05 & 3.08 & 20.82 & 0.86 \\
\hline \multirow{12}{*}{30} & \multirow{12}{*}{1.1} & 5 & \multirow{4}{*}{30} & 1.97 & 2.65 & 19.03 & 0.95 \\
\hline & & 10 & & 1.98 & 2.68 & 19.24 & 0.95 \\
\hline & & 15 & & 1.98 & 2.72 & 19.53 & 0.94 \\
\hline & & 20 & & 1.98 & 2.75 & 19.75 & 0.93 \\
\hline & & 5 & & 1.98 & 2.72 & 19.53 & 0.94 \\
\hline & & 10 & 60 & 1.98 & 2.75 & 19.75 & 0.93 \\
\hline & & 15 & & 1.99 & 2.79 & 20.03 & 0.93 \\
\hline & & 20 & & 1.99 & 2.82 & 20.25 & 0.92 \\
\hline & & 5 & & 2.02 & 3.17 & 22.76 & 0.86 \\
\hline & & 10 & 250 & 2.02 & 3.20 & 22.98 & 0.86 \\
\hline & & 15 & & 2.03 & 3.24 & 23.26 & 0.85 \\
\hline & & 20 & & 2.03 & 3.27 & 23.48 & 0.85 \\
\hline
\end{tabular}


Table 5 cont.

\begin{tabular}{|c|c|c|c|c|c|c|c|}
\hline \multirow{12}{*}{30} & \multirow{12}{*}{1.2} & 5 & \multirow{4}{*}{30} & 1.97 & 2.71 & 19.84 & 0.95 \\
\hline & & 10 & & 1.97 & 2.74 & 20.06 & 0.94 \\
\hline & & 15 & & 1.97 & 2.77 & 20.28 & 0.94 \\
\hline & & 20 & & 1.98 & 2.80 & 20.50 & 0.93 \\
\hline & & 5 & \multirow{4}{*}{60} & 1.97 & 2.78 & 20.35 & 0.93 \\
\hline & & 10 & & 1.98 & 2.81 & 20.57 & 0.93 \\
\hline & & 15 & & 1.98 & 2.85 & 20.86 & 0.92 \\
\hline & & 20 & & 1.98 & 2.88 & 21.08 & 0.92 \\
\hline & & 5 & \multirow{4}{*}{250} & 2.02 & 3.24 & 23.72 & 0.86 \\
\hline & & 10 & & 2.02 & 3.27 & 23.94 & 0.86 \\
\hline & & 15 & & 2.02 & 3.30 & 24.16 & 0.85 \\
\hline & & 20 & & 2.02 & 3.33 & 24.32 & 0.85 \\
\hline \multirow{12}{*}{30} & \multirow{12}{*}{1.4} & 5 & \multirow{4}{*}{30} & 1.96 & 2.86 & 21.74 & 0.93 \\
\hline & & 10 & & 1.96 & 2.89 & 21.96 & 0.93 \\
\hline & & 15 & & 1.97 & 2.92 & 22.19 & 0.92 \\
\hline & & 20 & & 1.97 & 2.95 & 22.42 & 0.92 \\
\hline & & 5 & \multirow{4}{*}{60} & 1.97 & 2.93 & 22.27 & 0.92 \\
\hline & & 10 & & 1.97 & 2.96 & 22.50 & 0.91 \\
\hline & & 15 & & 1.97 & 2.99 & 22.72 & 0.91 \\
\hline & & 20 & & 1.97 & 3.03 & 23.03 & 0.90 \\
\hline & & 5 & \multirow{4}{*}{250} & 2.01 & 3.39 & 25.77 & 0.85 \\
\hline & & 10 & & 2.01 & 3.42 & 25.99 & 0.85 \\
\hline & & 15 & & 2.01 & 3.45 & 26.22 & 0.84 \\
\hline & & 20 & & 2.02 & 3.48 & 26.45 & 0.84 \\
\hline
\end{tabular}

Despite the major discrepancies between the obtained values of $g$, the two approaches are both correct (although there are some differences in the way they should be interpreted). In the first approach, we get an indicator of the adequate roof-strata interactions under the fixed roof conditions. The second approach provides information that the load acting on the longwall site is increasing and that the roof-strata interactions tend to deteriorate.

At that stage of research work, it is reasonable to rely on Formulas (11)-(14) to prognosticate the loading $Q$ of the longwall site. However, it can be expected that, in further analyses investigating other longwall faces and various stages of the shield operation, the first approach may prove more useful.

\section{CONCLUSIONS}

The minimal bearing capacity of a powered support was obtained for the specified geological and mining conditions and for the given longwall equipment. The derived maximal value was $265 \mathrm{kN} / \mathrm{m}^{2}$, and the minimal value was found to be $95 \mathrm{kN} / \mathrm{m}^{2}$. The value obtained by the methodology in widespread use in Polish collieries was $200 \mathrm{kN} / \mathrm{m}^{2}$. The minimal working capacity of the investigated powered support was $720 \mathrm{kN} / \mathrm{m}^{2}$.

Data collected in the program registering longwall system performance were used in the analysis of the shield operation parameters taking into account the imposed constraints: maximal standstill time $t_{p}$ 
not exceeding $250 \mathrm{~min}$, maximal pressure $42 \mathrm{MPa}$, and the minimal pressure level $24 \mathrm{MPa}$.

Statistical analyses reveal that $41 \%$ of roof baring values fall within a range of $0.5 \mathrm{~m}$ to $0.6 \mathrm{~m}$.

During the standstill time of $60 \mathrm{~min}$, shields were moved towards the longwall face to support the roof, and $40 \%$ of the standstill times were registered throughout the analyzed period.

A relatively high number of registered standstill times did not exceed $10 \mathrm{~min}$ (38\% of the cases).

A pressure increase of $8 \mathrm{MPa}$ is registered in $57 \%$ of the cases, and the remaining $43 \%$ reveal a pressure increase of $10 \mathrm{MPa}$. It is reasonable to expect that the pressure distribution in particular pressure intervals follows a similar pattern.

A thorough analysis of the key parameter distributions has prompted the selection of criteria underpinning the shield operation models:

- standstill time within a range of 0 to $250 \mathrm{~min}$;

- roof baring process subdivided into intervals:

- $0.5 \mathrm{~m} \leq d<0.6 \mathrm{~m}$,

- $0.6 \leq d<0.9 \mathrm{~m}$,

- $0.9 \mathrm{~m} \leq d<1.2 \mathrm{~m}$,

- $1.2 \mathrm{~m} \leq d<1.4 \mathrm{~m}$.

For barred roof area intervals $0.5 \mathrm{~m} \leq d<0.6 \mathrm{~m}$ and $1.2 \mathrm{~m} \leq d<1.4 \mathrm{~m}$, the rate of face advance is found to be statistically insignificant.

Shield operation models taking into account all investigated predictors are found to be statically significant (Tab. 4), and the obtained corrected values of $R^{2}: 0.42 .0 .32 ; 12,11$ are regarded as satisfactory.

Respective models are governed by Equations (11)-(14), yielding a pressure level that can be interpreted as a loading acting on the longwall site $Q$ or the working capacity of the shield leg $P_{r}$. On this basis, the values of roof stability factor $g$ are obtained, indicating adequate shield-strata interactions in both cases. The initial and working bearing capacity under the conditions in the investigated longwall panel have been selected to leave a considerable safety margin.

At this stage of research work, the approach relying on shield monitoring data from the longwall panel and interpreting the predicted value of $p$ as load $Q$ acting on the longwall site appears to be more useful.

The results obtained thus far encourage the further development of the research methods and tools used in rock strata monitoring during longwall mining, offering us better insight into shield-strata interactions.

\section{References}

[1] Bołoz Ł.: Unique project of single-cutting head longwall shearer used for thin coal seams exploitation, "Archives of Mining Sciences" 2013, 58, 4: 1057-1070.

[2] Korzeniowski W., Herezy Ł. Krauze K., Rak Z., Skrzypkowski K.: Rock mass monitoring based on analysis of powered support response, Wydawnictwa AGH, Kraków 2013.

[3] Barczak T.M.: A retrospective assessment of longwall roof support with a focus on challenging accepted roof support concepts and design premises, 25th International Conference on Ground Control in Mining, Morgantown, West Virginia 2006.

[4] Barczak T.M., Esterhuizen G.S., Ellenberger J., Zahng P.: A first step in developing standing roof support design criteria based on ground reaction data for Pittsburgh seam longwall tailgate support, 27th International conference on ground control in mining, Morgantown, West Virginia 2008.

[5] Biliński A.: Principles of underground working maintenance in longwalls with rockburst hazard, "Archives of Mining Science" 1983, 28, 2: 275-291.

[6] Biliński A.: Metoda doboru obudowy ścianowych wyrobisk wybierkowych i chodnikowych do warunków pola eksploatacyjnego, Prace naukowe - monografie CMG Komag, Gliwice 2005.

[7] Hoyer D.: Early warning of longwall of cavities using LVA software, 12th Coal Operators' Conference, University of Wollongong \& the Australasian Institute of Mining and Metallurgy, Wollongong 2012.

[8] Trueman R., Lyman G., Cocker A.: Longwall roof control through a fundamental understanding of shield-strata interaction, "Journal of Rock Mechanics Mining Science" 2009, 46: 371-380.

[9] Trueman R., Callan M., Thomas R., Hoyer D.: Quantifying the impact of cover depth and panel width on longwall shieldstrata interactions, 10th Coal Operators Conference, Wollongong 2010.

[10] Trueman R., Thomas R., Hoyer D.: Understanding the causes of roof control problems on a longwall face from shield monitoring data - a case study, 11th Underground Coal Operators Conference, University of Wollongong \& the Australasian Institute of Mining and Metallurgy, Wollongong 2011.

[11] Mahmoud Y.S.: Estimation of bearing capacity of power support in front of longwall face, The Fourth Mining, Petroleum and Metallurgy Conference, Faculty of Engineering, Assiut University, Mining Engineering 1994, 1, 1: 251-255.

[12] Pawlikowski A.: Wpływ podporności wstępnej na podporność stojaków sekcji obudowy zmechanizowanej, "Mining - Informatics, Automation and Electrical Engineering" 2016, 4: 72-79.

[13] Płonka M.: Load variation of the set of support in the longwall with roof caving, "Research Reports Mining and Environment" 2009, 1: 41-49.

[14] Prusek S., Płonka A., Walentek A.: Applying the ground reaction curve concept to the assessment of shield support performance in longwall faces, "Arabian Journal of Geosciences" 2016, 9: 1-15.

[15] Pawlikowski A.: Przyczyny asymetrii podporności stojaków sekcji obudowy zmechanizowanej $w$ świetle badań dołowych, "Maszyny Górnicze" 2017, 1: 45-54.

[16] Szyguła M.: Progress in designing the powered roof support in Poland, "Maszyny Górnicze" 2013, 2: 30-38. 
[17] Cemal B., Ergin A.: Design of Supports in Mines, John Wiley \& Sons, New York 1983.

[18] Herezy Ł.: Predicting the vertical convergence of longwall headings basing on the pressure increase factor $\xi$, AGH University of Science and Technology, Kraków 2017 [unpublished work].

[19] Hussein M.A., Ibrahim A.R., Imbaby S.S.: Load calculations and selection of the powered supports based on rock mass classification and other formulae for Abu-Tartur longwall phosphate mining conditions, "Journal of Engineering Sciences" 2013, 41, 4: 1728-1742.

[20] Herezy Ł.: Relationship between vertical convergence of longwall headings and the pressure increase factor $\xi$ for a powered support section, AGH University of Science and Technology, Krakow 2017 [unpublished].
[21] Przegendza G., Przegendza M.: Control and diagnostics systems for mining machines and equipment using a CAN bus, "Szybkobieżne Pojazdy Gąsienicowe" 2007, 2: 1-11.

[22] https://www.statsoft.pl/textbook/stathome.html [online], September 2017.

ŁUKASZ HEREZY, Ph.D., Eng. WALDEMAR KORZENIOWSKI, prof. KRZYSZTOF SKRZYPKOWSKI, Ph.D., Eng. Underground Mining Department Faculty of Mining and Geoengineering AGH University of Science and Technology al. Mickiewicza 30, 30-059 Krakow, Poland \{herezy,walkor,skrzypo\}@agh.edu.pl 


\title{
Określenie założeń modelu matematycznego pracy sekcji obudowy zmechanizowanej w zakresie jej podporności roboczej
}

\begin{abstract}
W artykule postużono się zgromadzonymi danymi dotyczacymi pracy kompleksu ścianowego, aby wyznaczyć wpływ czasu, wytrzymatości skat stropowych na ściskanie, postępu ściany, odległości stropnicy sekcji od ociosu na wartość osiaganej podporności roboczej. W tym celu w programie Statistica wykonano analizy z wykorzystaniem ogólnych modeli liniowych. Przyjęte kryteria danych wejściowych pozwolity na uzyskanie modeli pracy sekcji o skorygowanym R2 wynoszacym 0,11-0,42, kwalifikujacym te modele jako istotne statystycznie. Dla rozpatrywanego pola ścianowego określono wymagana minimalna podporność robocza sekcji dla kilku sposobów jej wyznaczania $i$ porównano z podpornościa zastosowanych sekcji obudowy. Następnie na podstawie modeli matematycznych wyznaczono wartość ciśnienia roboczego, które można wykorzystać jako:

- ciśnienie $w$ stojaku hydraulicznym i na jego podstawie obliczyć podporność stojaka hydraulicznego będąca reakcją na obciażenie sekcji,

- ciśnienie wywierane przez górotwór na wyrobisko eksploatacyjne, z którego można wyznaczyć rzeczywiste obciażenie sekcji obudowy zmechanizowanej.
\end{abstract}

Dla obydwu założeń wyznaczono wskaźnik nośności stropu. Jego wartości świadcza o bardzo dobrej wspótpracy sekcji z górotworem w rozpatrywanych warunkach geologiczno-górniczych.

Słowa kluczowe: ciśnienie robocze, podporność obudowy, system ścianowy, obciażenie wyrobiska ścianowego

\section{WSTĘP}

Ścianowy system eksploatacji jest jednym z najpopularniejszych na świecie. W porównaniu z drugim co do popularności systemem komorowo-filarowym odznacza się lepszymi wynikami eksploatacyjnymi. Jednakże wyposażenie maszynowe konieczne do jego zastosowania jest bardzo drogie. Wyposażenie to nazywane jest kompleksem ścianowym, na który składają się maszyna urabiająca (kombajn ścianowy lub głowica strugowa wraz z jej napędem), przenośnik ścianowy i podścianowy zgrzebłowy, obudowa zmechanizowana, pociąg aparaturowy oraz hydrauliczny zespół zasilający. Prawidłowo dobrane poszczególne urządzenia kompleksu zarówno do warunków geologiczno-górniczych, jak i do współpracy powinny gwarantować użytkownikowi prowadzenie niezakłóconej eksploatacji, której wynikiem będzie osiągnięcie wydobycia na zakładanym poziomie $[1,2]$. Pierwszymi kryteriami doboru maszyn są wysokość eksploatacji (wysokość pokładu), podłużny i poprzeczny kąt nachylenia wyrobiska ścianowego. Jeżeli maszyny kompleksu zostały zaprojektowane do współpracy ze sobą wówczas sprawdzenie ich pod tym kątem jest zbędę. W przypadku jednak, gdy wyposażenie ściany składa się z maszyn różnych producentów lub różnych projektowanych kompleksów tego samego producenta należy sprawdzić możliwości techniczne ich współpracy. Kolejnym krokiem jest sprawdzenie wydajności urabiania maszyny i zdolności odbioru urobku przenośnika dla osiągnięcia zakładanego wydobycia dobowego. W przypadku obudowy zmechanizowanej prócz warunków technicznych 
należy sprawdzić jej współpracę z górotworem zapewniającą stateczność stropu nad przestrzenią roboczą wyrobiska ścianowego [3-10]. Zapewnienie prawidłowej współpracy sekcji obudowy ze stropem wynika z prawidłowego doboru jej parametrów techniczno-ruchowych $[4,11,12]$. Zmienna w czasie podporność robocza jest reakcją na obciążenie sekcji obudowy pochodzące od skał stropowych. Składowymi mającymi wpływ na wartość obciążenia sekcji są między innymi $[3,6,13,14]$ :

- ciśnienie górotworu związane z głębokością eksploatacji, zaszłościami eksploatacyjnymi, kątem nachylenia pokładu,

- wytrzymałość na ściskanie skał stropowych,

- rozpiętość wyrobiska ścianowego rozumianą jako odległość od czoła ściany do miejsca tworzenia się zawału,

- czas postoju sekcji.

Prawidłowy dobór obudowy do warunków geologiczno-górniczych nie zawsze gwarantuje nam prawidłową współpracę ze stropem. Do osiągnięcia zadanej i jednakowej podporności wstępnej w stojakach sekcji obudowy stosuje się układy sterowania z układem wtórnego doładowania. Jednakże $w$ warunkach słabych stropów, gdzie przy zbyt dużym ciśnieniu wstępnym możemy niszczyć skały stropowe układ ten jest często wyłączany przez operatorów $[12,15,16]$. Brak jego działania powoduje nierównomierne ciśnienie w stojakach oraz niejednokrotnie niedostateczne rozparcie sekcji. W konsekwencji dopuszczamy do powstawania opadów, obwałów, a nawet zawałów skał stropowych oraz do przeciążeń elementów sekcji obudowy.

\section{METODY DOBORU I SPRAWDZENIA WSPÓKPRACY SEKCJI OBUDOWY Z GÓROTWOREM}

W warunkach polskich w celu sprawdzenia współpracy sekcji obudowy z górotworem posługujemy się metodą dopuszczalnego ugięcia stropu $[6,13,14]$.

Warunek dobrego utrzymania stropu zostanie spełniony wówczas, gdy wartość wskaźnika nośności stropu $g$ wynosi co najmniej 0,8 . Jest to wartość graniczna, poniżej której występuje zagrożenie obwałem skał stropowych i złe warunki utrzymania stropu. Przyjęto, że przy wskaźnikach nośności stropu w przedziale $0,7 \leq g<0,8$ należy się liczyć $\mathrm{z}$ utrudnieniami $\mathrm{w}$ prowadzeniu ściany. Utrudnienia związane są z ryzykiem opadu skał stropowych lub przemieszczeniem pionowym bloków skalnych [6].
Do określenia wartości wskaźnika nośności stropu $g$ korzysta się ze wzoru [6]:

$$
g=\frac{1}{\frac{0,65 \cdot z_{1}}{z_{g}}+0.3}
$$

gdzie:

$z_{1}$ - jednostkowe nachylenie stropu,

$z_{g}$ - wartość granicznego nachylenia stropu.

Po przekroczeniu granicznej wartości osiadania następuje rozpad warstwy skalnej. Graniczna wartość osiadania jest różna w zależności od rodzaju skał. $\mathrm{Na}$ podstawie obserwacji prowadzonych w wyrobiskach ścianowych można określić wartość granicznego nachylenia stropu utworzonego z danego rodzaju skał, po przekroczeniu której staje się on zbiorowiskiem luźnych bloków skalnych. Wartość ta wyraża się nachyleniem stropu $z_{g}$ w milimetrach przypadającym na $1 \mathrm{~m}$ rozpiętości stropu [6]:

$$
z_{g}=\frac{k_{e}}{\frac{0,05}{R_{c s}}+0,006}\left[\frac{\mathrm{mm}}{\mathrm{m}}\right]
$$

gdzie:

$k_{e}$ - współczynnik zależny od systemu eksploatacji (dla zawału 0,8, dla podsadzki hydraulicznej 0,35),

$R_{c s}$ - wytrzymałość na ściskanie skał stropowych [MPa].

Wartość jednostkowego nachylenia stropu $z_{1}[\mathrm{~mm} / \mathrm{m}]$, czyli nachylenia występującego na pierwszym metrze rozpiętości wyrobiska od czoła ściany, jest czynnikiem decydującym o wielkości osiadania stropu nad całym wyrobiskiem ścianowym.

W przypadku ścian zawałowych wartość $z_{1}$ wylicza się ze wzoru [6]:

$$
z_{1}=\frac{1}{0,013 m_{p}+0,002}\left[\frac{\mathrm{mm}}{\mathrm{m}}\right]
$$

gdzie $m_{p}$ - stosunek wartości momentu podporności obudowy $M_{p}[\mathrm{MN} \cdot \mathrm{m}]$ do wartości momentu obciążenia wyrobiska $M_{Q}[\mathrm{MN} \cdot \mathrm{m}]$.

Przy obliczaniu jednostkowego nachylenia stropu niezbędne jest wyznaczenie momentu wypadkowej podporności sekcji obudowy zmechanizowanej $M_{p}$ oraz podporności średniej obudowy zmechanizowanej $P_{z}$ (wzór (4)), która jest obliczana dla odcinka ściany, na którym jedna z sekcji rozparta jest podpornością wstępną, druga przemieszczana jest w kierunku 
ociosu, kolejna nie została jeszcze przesunięta, a ciśnienie $\mathrm{w}$ stojakach znajduje się w górnym zakresie ciśnienia roboczego lub w zakresie ciśnienia nominalnego. Jest to najmniej korzystna sytuacja w trakcie normalnej pracy obudowy ścianowej [6]:

$$
\begin{aligned}
& P_{z}=\frac{i \cdot n_{k} \cdot n_{w} \cdot P_{r}}{3 b} . \\
& {\left[\frac{\left(1-n_{0}\right) \cdot\left(d_{02}-d_{01}\right)}{\frac{100 \cdot e^{-3,5 \cdot e^{-8 n_{c z}}}}{z_{\text {śr }}}+\left(1+e^{-1,8 \cdot e^{-2 n_{c z}}}\right)}+2 \cdot n_{m} \cdot n_{0}\right][\mathrm{MN}]}
\end{aligned}
$$

gdzie:

$i$ - liczba stojaków hydraulicznych obudowy zmechanizowanej,

$n_{k}$ - współczynnik redukcyjny podporności stojaka,

$n_{w}$ - współczynnik przenoszenia podporności sekcji obudowy na strop wyrobiska,

$P_{r}$ - podporność robocza stojaków sekcji obudowy zmechanizowanej [MN],

$n_{0}$ - stosunek podporności wstępnej do podporności roboczej,

$n_{0}=\frac{P_{w}}{P_{r}}$

$P_{w}$ - podporność wstępna stojaków sekcji obudowy zmechanizowanej [MN],

$d_{02}-d_{01}$ - odległość początkowa i końcowa od czoła ściany rozpatrywanego odcinka rozpiętości wyrobiska $[\mathrm{m}]$,

$n_{c z}$ - współczynnik pracy obudowy,

$z_{s r}$ - średnia wartość zaciskania wyrobiska ścianowego na odcinku $d_{02}-d_{01}$,

$n_{m}$ - współczynnik wpływu małej wytrzymałości otoczenia.

Moment podporowy obudowy zmechanizowanej wynosi [6]:

$$
M_{p}=P_{z} \cdot l_{z} \quad[\mathrm{MN} \cdot \mathrm{m}]
$$

gdzie $l_{z}-$ ramię działania siły podporności $P_{z}$.

Ciężar górotworu działający na wyrobisko ścianowe jest równy ciężarowi wycinka bryły górotworu o szerokości $1 \mathrm{~m}$, licząc wzdłuż frontu ściany, oraz długości podstawy prostopadłej do tego frontu, równej rozpiętości wyrobiska. Wysokość wycinka oraz kształt ścian bocznych zależy od przyjętego systemu eksploatacji i wytrzymałości stropu.
Obciążenie wyrobiska ścianowego przypadające na $1 \mathrm{~m}$ bieżący jego długości, w systemie z zawałem stropu wynosi:

$$
Q=n_{q} \cdot n_{a} \cdot h_{s} \cdot c_{w} \frac{L_{i}^{1,4}}{0,13 \cdot R_{c}^{0,5}+0,7} \quad[\mathrm{MN}]
$$

gdzie:

$n_{q}$ - współczynnik nasilenia obciążenia,

$n_{q}$ - współczynnik zasięgu górotworu odprężonego,

$c_{w}$ - ciężar objętościowy skał stropowych $\left[\mathrm{MN} / \mathrm{m}^{3}\right]$,

$h_{s}$ - zredukowana wysokość wyrobiska eksploatacyjnego [m],

$L_{i}$ - rozpiętość wyrobiska [m],

$R_{c}$ - wytrzymałość skał stropowych na ściskanie [MPa].

Moment obciążenia wyrobiska ścianowego wynosi [6]:

$$
M_{Q}=0,7 \cdot L_{i} \cdot Q \quad[\mathrm{MN} \cdot \mathrm{m}]
$$

Określenie minimalnej podporności roboczej sekcji obudowy można wykonać, posługując się wzorem:

$$
P=\frac{Q}{0,7}(g-0,3) \quad[\mathrm{MN}]
$$

W równaniu (9) za wartość współczynnika $g$ należy wstawić co najmniej 0,8 , aby zagwarantować dobre warunki utrzymania stropu [17].

W krajach o rozwiniętym górnictwie na bazie własnych doświadczeń opracowano metody doboru podporności sekcji obudowy.

Na przykład w Wielkiej Brytanii [6] stosuje się do obliczenia minimalnej podporności sekcji wzór:

$$
P \geq \frac{m}{k-1} \cdot \gamma\left[\frac{\mathrm{Mg}}{\mathrm{m}^{2}}\right]
$$

Dla wybranych metod dokonano obliczeń minimalnej podporności roboczej dla opisanych w pkt 3 warunków geologiczno-górniczych, ich wyniki przedstawiono w tabeli 1.

Tabela 1

Wyniki obliczeń minimalnej podporności sekcji obudowy dla wybranych metod

\begin{tabular}{|c|l|c|}
\hline Lp. & \multicolumn{1}{|c|}{ Metoda } & $\begin{array}{c}\text { Minimalna podporność } \\
\text { sekcji obudowy } \\
\boldsymbol{P}_{\min }\left[\mathbf{k N} / \mathbf{m}^{2}\right]\end{array}$ \\
\hline 1 & Polska [17] & 200 \\
\hline 2 & Wielka Brytania [17] & 267 \\
\hline 3 & Niemcy [17] & 214 \\
\hline 5 & Terzaghi [11] & 128 \\
\hline 5 & Yehia [19] & 95 \\
\hline
\end{tabular}




\section{WARUNKI GEOLOGICZNO-GÓRNICZE}

Rozpatrywane pole ścianowe zalegało prawie poziomo, nachylenie wzdłużne przecinki ścianowej wynosiło $2^{\circ}$. Miąższość pokładu zmieniała się w granicach 1,33-1,8 m wokół wartości średniej wynoszącej $1,6 \mathrm{~m}$. W pokładzie występowały przerosty iłowcowe o miąższości około $0,1 \mathrm{~m}$ i wytrzymałości na ściskanie w zakresie 15-32 MPa. Wytrzymałość węgla wahała się w granicach 12-18 MPa. Zaprojektowana ściana eksploatacyjna miała długość $250 \mathrm{~m}$ przy wybiegu wynoszącym $1750 \mathrm{~m}$.

W analizowanym rejonie strop bezpośredni stanowiły warstwy iłowca, mułowca i piaskowca. Miąższość iłowca występującego bezpośrednio nad pokładem wahała się od $0,8 \mathrm{~m}$ do 2,0 $\mathrm{m}$. Lokalnie stwierdzono występowanie buł sferosyderytów. Bezpośrednio nad iłowcem zalegała warstwa mułowca o miąższości od $0,2 \mathrm{~m}$ do ponad $7,0 \mathrm{~m}$. Największą miąższość mułowca obserwowano w środkowej części wybiegu ściany. Nad mułowcem zalegała warstwa piaskowca o miąższości do 7,0 m, miejscami przewarstwiona pojedynczymi wkładkami mułowca. Najgrubszą ławę piaskowca stwierdzono na początku wybiegu ściany. Powyżej piaskowca zalegały naprzemianległe warstwy mułowców i iłowców oraz węgla.

W spągu pokładu, praktycznie na całej długości wybiegu ściany, występowała warstwa iłowca o grubości od $0,3 \mathrm{~m}$ do niespełna $1,5 \mathrm{~m}$. Poniżej układ warstw był zmienny, tj. na przemian występował mułowiec, piaskowiec oraz iłowiec, a lokalnie także węgiel. W rejonie nie stwierdzono zaburzeń tektonicznych i sedymentacyjnych. Na podstawie otworów badawczych wykonanych $\mathrm{w}$ wyrobiskach przyścianowych rozpatrywanego pola wykonano mapę wytrzymałości skał stropowych nad polem ścianowym (rys. 1).

W trakcie prac badawczych w bezpośrednim sąsiedztwie analizowanej ściany nie prowadzono eksploatacji. Można zatem przyjąć, że w trakcie jej wybierania przemieszczenia górotworu w rozważanym obszarze będą wynikiem przede wszystkim ciśnienia pierwotnego górotworu oraz ciśnienia eksploatacyjnego.
Wyrobisko ścianowe zostało uzbrojone w kompleks strugowy, w którego skład wchodziły:

- strug GH 1600 przystosowany do eksploatacji pokładów o miąższości 0,98-2,2 m; w ścianie zastosowano najniższą wersję o wysokości 980 $1230 \mathrm{~mm}$;

- przenośnik ścianowy PF-1032 z czołowym wysypem;

- przenośnik podścianowy PF-1132;

- sekcje obudowy zmechanizowanej, łącznie 141 sztuk; od strony chodnika podścianowego zazbrojono trzy sztuki sekcji skrajnej, następnie sekcję liniową 9,5/20 w liczbie 134 sztuk i cztery sztuki sekcji skrajnej; parametry techniczne sekcji przedstawiono w tabeli 2.

Parametry sekcji i warunki rozpatrywanego pola ścianowego pozwoliły na obliczenie wskaźnika nośności stropu $g$ na poziomie około 1,4 . Sekcje przy takim wskaźniku powinny zapewnić bardzo dobre utrzymanie stropu w wyrobisku eksploatacyjnym.

Tabela 2

Parametry techniczno-ruchowe sekcji obudowy zmechanizowanej

\begin{tabular}{|l|l|c|c|}
\hline \multicolumn{2}{|c|}{ Parametr } & Wartość & Jednostka \\
\hline Zakres wysokości obudowy & $0,95-2,0$ & {$[\mathrm{~m}]$} \\
\hline Zakres pracy obudowy & $1,0-1,9$ & {$[\mathrm{~m}]$} \\
\hline \multirow{2}{|l|}{$\begin{array}{l}\text { Dopuszczalne } \\
\text { nachylenie }\end{array}$} & podłużne & do $15^{\circ}$ & {$[-]$} \\
\cline { 2 - 4 } & poprzeczne & $\pm 15^{\circ}$ & {$[-]$} \\
\hline \multicolumn{2}{|l|}{ Podziałka obudowy } & 1,75 & {$[\mathrm{~m}]$} \\
\hline Krok obudowy & do 0,85 & {$[\mathrm{~m}]$} \\
\hline Liczba stojaków hydraulicznych & 2 & {$[\mathrm{szt}]$.} \\
\hline Średnica stojaka & $\varnothing 320$ & {$[\mathrm{~mm}]$} \\
\hline $\begin{array}{l}\text { Podporność } \\
\text { stojaka }\end{array}$ & wstępna (32 MPa) & 2,573 & {$[\mathrm{MN}]$} \\
\cline { 2 - 4 } & robocza (45 MPa) & 3,619 & {$[\mathrm{MN}]$} \\
\hline \multicolumn{2}{|l|}{ Długość stropnicy } & 4030 & {$[\mathrm{~mm}]$} \\
\hline \multicolumn{2}{|l|}{ Ciśnienie robocze } & 45 & {$[\mathrm{MPa}]$} \\
\hline \multicolumn{2}{|l|}{ Ciśnienie zasilania } & 32 & {$[\mathrm{MPa}]$} \\
\hline
\end{tabular}

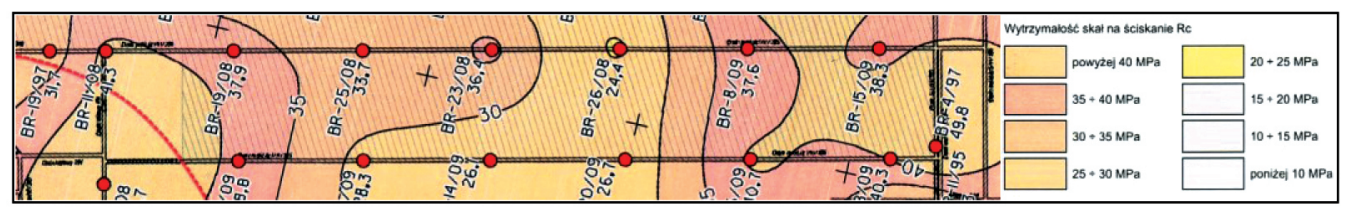

Rys. 1. Mapa wytrzymatości $R_{c}$ dla pakietu skat zalegających do $6 \mathrm{~m}$ od stropu poktadu (wyk. A. Ruchel) 


\section{ANALIZA DANYCH UZYSKANYCH Z PROGRAMU V-SHIELD}

W rozpatrywanym wyrobisku ścianowym obudowa składała się ze 141 sekcji. Jednym z podstawowych elementów wyposażenia kompleksu był system sterowania i wizualizacji pracy zarówno sekcji, jak i pozostałych maszyn i urządzeń kompleksu ścianowego. Podstawowymi danymi wykorzystanymi do analiz pozyskanych z systemu wizualizacji były $[2,18$, 20, 21]:

- $p$ - ciśnienie w części podtłokowej stojaków hy-

draulicznych sekcji obudowy [MPa],

- $w$ - wysuw siłownika przekładkowego [m],

- $v$ - postęp ściany [m/24 h],

- $t_{p}$ - czas postoju sekcji obudowy [min].

W analizach zamiast wartości wysuwu siłownika przekładkowego posłużono się wielkością odsłonięcia stropu $d[\mathrm{~m}]$ oznaczającą odległość końca stropnicy (od strony czoła ściany) do czoła ściany. Odległość $d$ to składowa odległości technicznej $L_{t}$ końca stropnicy od czoła ściany (wynikającej z budowy kompleksu ścianowego przed wykonaniem zabioru) i wielkości zabioru $z$ maszyny urabiającej. Dla rozpatrywanego kompleksu ścianowego odległość $L_{t}$ wynosi $0,5 \mathrm{~m}$, a maksymalny założony zabiór $0,7 \mathrm{~m}$. Maksymalne założone odsłonięcie stropu $d$ powinno wynosić 1,2 m, w praktyce największa wartość wynosiła 1,4 m.

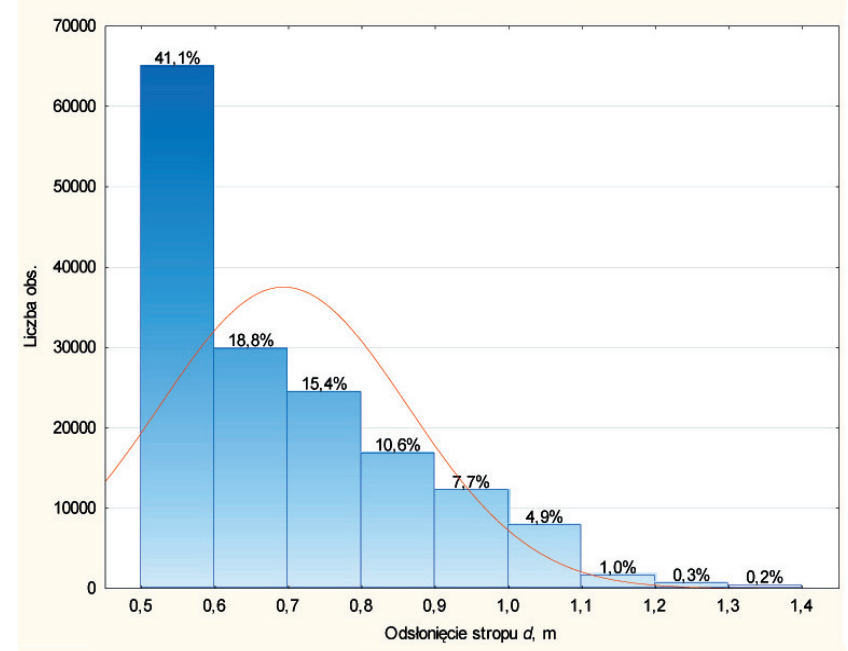

Rys. 2. Rozktad wartości odstonięcia stropu d
Uwzględniając wyniki badań $[2,18,20]$, do analiz przyjęto:

- sekcje od 30 do 110 ,

- maksymalny czas postoju $t_{p}$ przyjęto nie większy niż 250 min (w tym czasie sekcja pracuje jeszcze w zakresie ciśnienia roboczego),

- maksymalną wartość ciśnienia $42 \mathrm{MPa}$,

- minimalną wartość ciśnienia $24 \mathrm{MPa}$.

$\mathrm{Z}$ rysunku 2 wynika, że $41 \%$ wartości odsłonięcia stropu mieści się $\mathrm{w}$ przedziale od $0,5 \mathrm{~m}$ do $0,6 \mathrm{~m}$. Zbliżoną wartość procentową mają parametry odsłonięcia stropu w przedziale od $0,6 \mathrm{~m}$ do $0,9 \mathrm{~m}$ - wynosi ona $44,8 \%$. Pozostały przedział odsłonięcia stropu do wartości nominalnej zabioru 1,2 m wynosi 13,6\%. Jedynie $0,5 \%$ ze wszystkich wartości $d$ przekracza wartość nominalną 1,2 $\mathrm{m}$. Na rysunku 3 przedstawiono rozkład ciśnienia w stojakach $p$. Podczas przyrostu ciśnienia o $8 \mathrm{MPa}$ (od $24 \mathrm{MPa}$ do $32 \mathrm{MPa}$ ) obserwuje się 57\% odczytanych danych, pozostałe $43 \%$ przypada na przyrost kolejnych $10 \mathrm{MPa}$ (od $32 \mathrm{MPa}$ do $42 \mathrm{MPa}$ ). Zdecydowanie dominującymi prędkościami postępu ściany, których udział w całości danych wynosi $34 \%$, są postępy w przedziale 10-12 m/dobę (rys. 4). Odzwierciedleniem rozkładu odsłonięcia stropu $d$ jest rozkład czasu postoju $t_{p}$ sekcji (rys. 5). Wynika z niego, że 38\% zarejestrowanych postojów nie przekracza 10 min. Na czas niezbędnego do wykonania pełnego zabioru $(z=0,7 \mathrm{~m})$, wynoszącego $27 \mathrm{~min}$, przypada $60 \%$ rejestrowanych postojów. Pozostałe $40 \%$ odnosi się do wartości odsłonięcia stropu powyżej 1,2 m.

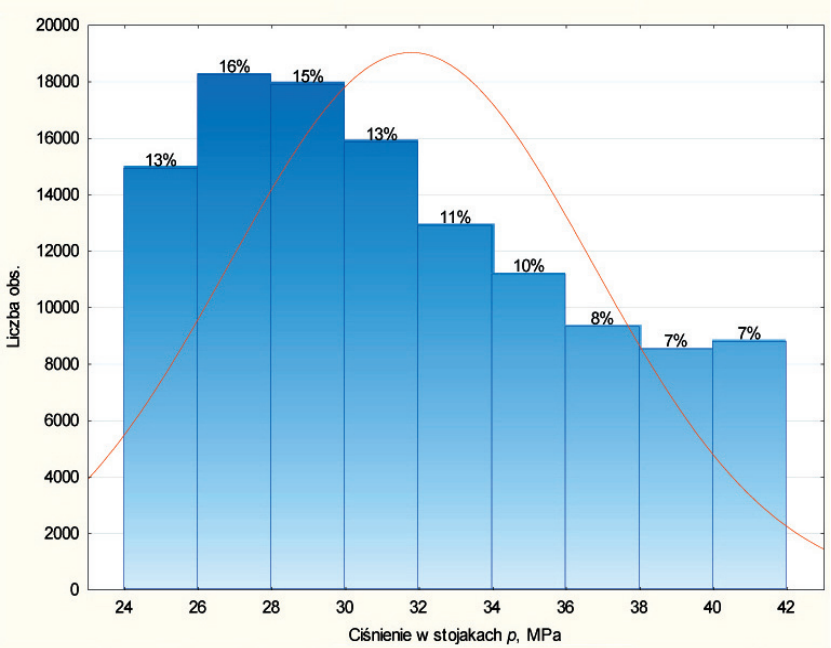

Rys. 3. Rozkład wartości ciśnienia w stojakach $p$ 


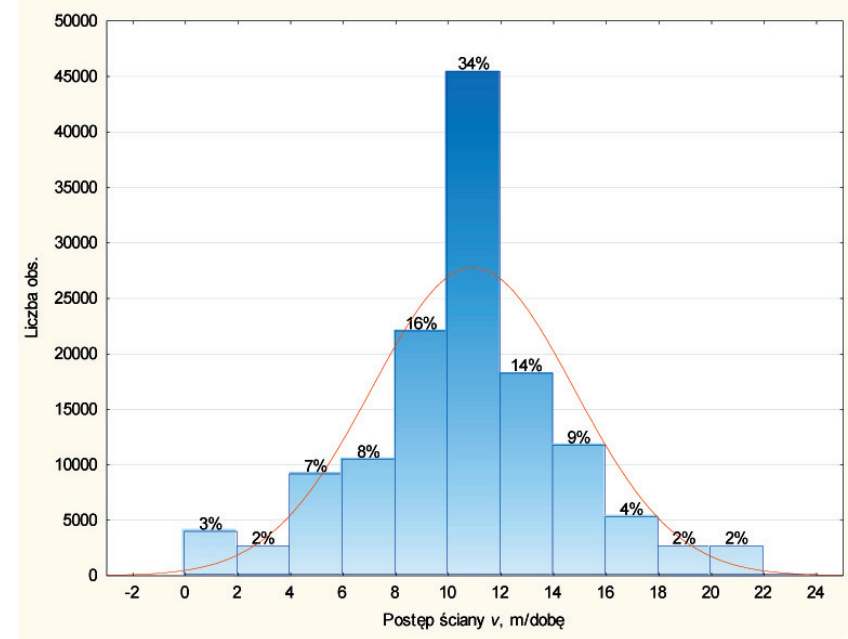

Rys. 4. Rozkład wartości postępu ściany v

\section{WIELOPARAMETRYCZNY MODEL PRACY SEKCJI}

Do wyznaczenia modelu pracy sekcji wykorzystano model liniowy - często służy on do analizy dowolnych układów ANOVA lub MANOVA zawierających predyktory skategoryzowane, dowolne układy ANCOVA lub MANCOVA zawierające zarówno skategoryzowane, jak i ciągłe zmienne objaśniające oraz dowolne układy regresji wielorakiej i wielowymiarowej. W modelu tym istnieją dwie metody kodowania i analizy zmiennych: do analizy danych pomiarowych Statistica dopasowała Model z sigmaograniczeniami (sposób kodowania predyktorów jakościowych). Przy użyciu tej metody można przypisać dwie dowolne, umowne, ale różne wartości pojedynczej zmiennej objaśniającej (predyktora). Otrzymane wartości zmiennej objaśniającej będą przedstawiać ujętą ilościowo przynależność do grup. Wartości odpowiadające przynależności do grup nie są zazwyczaj wybierane w dowolny sposób, lecz tak, aby ułatwić interpretację wielkości współczynnika regresji powiązanego ze zmienną objaśnianą (predyktorem). W jednej z szeroko wykorzystywanych strategii przypadkom należącym do dwóch grup są przypisywane wartości zmiennej objaśniającej równe 1 i -1, dzięki czemu, w przypadku gdy współczynnik regresji dla zmiennej jest dodatni, wówczas grupa zakodowana w zmiennej objaśniającej za pomoca 1 będzie miała wyższą przewidywaną wartość (tzn. wyższą wartość średniej grupowej) zmiennej zależnej, a gdy współczynnik regresji jest ujemny, wówczas grupa kodowana jako -1 w obrębie zmiennej

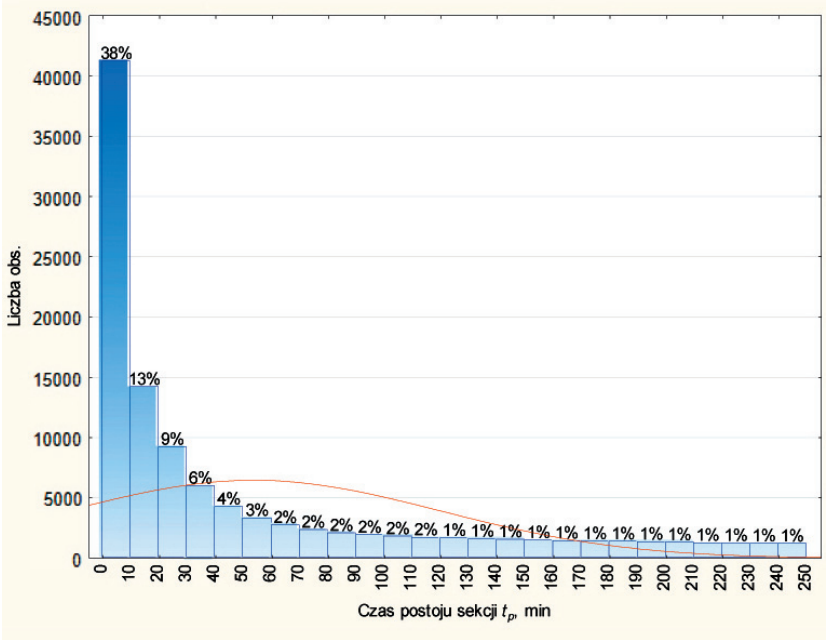

Rys. 5. Rozkład czasu postoju sekcji $t_{p}$

objaśniającej będzie miała wyższą przewidywaną wartość zmiennej zależnej. Dodatkowa zaleta tego podejścia polega na tym, że każda $z$ grup jest kodowana za pomocą wartości różniącej się o jeden od zera, co pomaga $\mathrm{w}$ interpretacji wielkości różnic wartości przewidywanych pomiędzy grupami, ponieważ współczynniki regresji charakteryzują jednostkową zmianę zmiennej zależnej dla każdej jednostkowej zmiany zmiennej objaśniającej (predyktora). Ta strategia kodowania jest trafnie nazywana parametryzacja z sigmaograniczeniami ze względu na to, że wartości używane do oznaczenia przynależności do grupy (1 i-1) sumują się do zera [22].

Przyjmowano wiele wariantów obliczeniowych zarówno z podziałem czasu postoju, jak i odsłonięcia stropu w różnych przedziałach i wzajemnych konfiguracjach. Najbardziej optymalnymi wskaźnikami statystycznymi (tab. 3) charakteryzowała się konfiguracja parametrów, gdzie:

- czas postoju sekcji $t_{p}$ zawierał się w przedziale od $0 \mathrm{~min}$ do $250 \mathrm{~min}$,

- odsłonięcie stropu podzielono na przedziały;

- $0,5 \mathrm{~m} \leq d<0,6 \mathrm{~m}$,

- $0,6 \mathrm{~m} \leq d<0,9 \mathrm{~m}$,

- $0,9 \mathrm{~m} \leq d<1,2 \mathrm{~m}$,

- $1,2 \mathrm{~m} \leq d<1,4 \mathrm{~m}$.

Dla przedziałów odsłonięcia stropu $0,5 \mathrm{~m} \leq d<0,6 \mathrm{~m}$, $1,2 \mathrm{~m} \leq d<1,4 \mathrm{~m}$ parametrem nieistotnym statystycznie okazał się postęp ściany $v$.

Po analizie całości poszczególnych modeli okazały się one istotnie statystycznie, a otrzymany skorygowany $R^{2}$ (tab. 4) można uznać za zadowalający. 
Tabela 3

Ocena istotności parametrów modeli

\begin{tabular}{|c|c|c|c|c|c|c|c|c|c|c|}
\hline Efekt & $\begin{array}{c}\text { Ciśnienie } \\
\text { w } \\
\text { stojakach, } \\
p[\mathrm{MPa}] \\
\end{array}$ & \begin{tabular}{|c|}
$\begin{array}{c}\text { Ciśnienie } \\
\text { w } \\
\text { stojakach, } \\
p[\mathrm{MPa}]\end{array}$ \\
\end{tabular} & \begin{tabular}{|c|}
$\begin{array}{c}\text { Ciśnienie } \\
\text { w } \\
\text { stojakach, } \\
p[\mathrm{MPa}]\end{array}$ \\
\end{tabular} & \begin{tabular}{|c|}
$\begin{array}{c}\text { Ciśnienie } \\
\text { w } \\
\text { stojakach, } \\
p[\mathrm{MPa}]\end{array}$ \\
\end{tabular} & $\begin{array}{c}-95,00 \\
{[\%]}\end{array}$ & $\begin{array}{c}+95,00 \\
{[\%]}\end{array}$ & \begin{tabular}{|c|} 
Ciśnienie \\
w \\
stojakach, \\
$p[\mathrm{MPa}]$ \\
\end{tabular} & \begin{tabular}{|c|}
$\begin{array}{c}\text { Ciśnienie } \\
\text { w } \\
\text { stojakach, } \\
p[\mathrm{MPa}]\end{array}$ \\
\end{tabular} & $\begin{array}{c}-95,00 \\
{[\%]}\end{array}$ & $\begin{array}{c}+95,00 \\
{[\%]}\end{array}$ \\
\hline \multicolumn{11}{|c|}{$\begin{array}{c}\text { Parametryzacja z sigmaograniczeniami } \\
\text { Warunek uwzględniania: } d \geq 0,5 \mathrm{~m} ; d<0,6 \mathrm{~m} ; p \geq 24 \mathrm{MPa} ; p \leq 42 \mathrm{MPa} ; t_{p} \leq 250 \mathrm{~min}\end{array}$} \\
\hline Wyraz wolny & 42,271 & 0,471 & 89,661 & 0,000 & 41,347 & 43,195 & & & & \\
\hline $\begin{array}{l}\text { Współczynnik wpły- } \\
\text { wu odsłonięcia stropu }\end{array}$ & $-20,62$ & 0,792 & $-26,04$ & 0,000 & $-22,17$ & $-19,06$ & $-0,118$ & 0,005 & $-0,127$ & $-0,109$ \\
\hline $\begin{array}{l}\text { Współczynnik wpły- } \\
\text { wu postępu ściany }\end{array}$ & $-0,010$ & 0,005 & $-1,888$ & 0,059 & $-0,020$ & $\mathbf{0 , 0 0 0}$ & $-0,009$ & 0,005 & $-0,018$ & 0,000 \\
\hline $\begin{array}{l}\text { Współczynnik wpły- } \\
\text { wu wytrzymałość na } \\
\text { ściskanie skał stro- } \\
\text { powych }\end{array}$ & $-0,095$ & 0,005 & $-17,91$ & 0,000 & $-0,105$ & $-0,084$ & $-0,081$ & 0,005 & $-0,090$ & $-0,072$ \\
\hline $\begin{array}{l}\text { Współczynnik wpły- } \\
\text { wu czasu postoju } \\
\text { sekcji }\end{array}$ & 0,037 & 0,000 & 132,1 & 0,000 & 0,036 & 0,037 & 0,621 & 0,005 & 0,611 & 0,630 \\
\hline \multicolumn{11}{|c|}{ Warunek uwzględniania: $d \geq 0,6 \mathrm{~m} ; d<0,9 \mathrm{~m} ; p \geq 24 \mathrm{MPa} ; p \leq 42 \mathrm{MPa} ; t_{p} \leq 250 \mathrm{~min}$} \\
\hline Wyraz wolny & 25,763 & 0,190 & 135,87 & 0,000 & 25,391 & 26,134 & & & & \\
\hline $\begin{array}{l}\text { Współczynnik wpły- } \\
\text { wu odsłonięcie stropu }\end{array}$ & 8,577 & 0,183 & 46,769 & 0,000 & 8,217 & 8,936 & 0,176 & 0,004 & 0,168 & 0,183 \\
\hline $\begin{array}{l}\text { Współczynnik wpły- } \\
\text { wu postępu ściany }\end{array}$ & $-0,032$ & 0,004 & $-7,286$ & 0,000 & $-0,041$ & $-0,024$ & $-0,028$ & 0,004 & $-0,035$ & $-0,020$ \\
\hline $\begin{array}{l}\text { Współczynnik wpły- } \\
\text { wu wytrzymałość } \\
\text { na ściskanie skał } \\
\text { stropowych }\end{array}$ & $-0,098$ & 0,004 & $-24,84$ & 0,000 & $-0,106$ & $-0,090$ & $-0,093$ & 0,004 & $-0,101$ & $-0,086$ \\
\hline $\begin{array}{l}\text { Współczynnik wpły- } \\
\text { wu czasu postoju } \\
\text { sekcji }\end{array}$ & 0,038 & 0,000 & 138,48 & 0,000 & 0,037 & 0,038 & 0,528 & 0,004 & 0,521 & 0,536 \\
\hline \multicolumn{11}{|c|}{ Warunek uwzględniania: $d \geq 0,9 \mathrm{~m} ; d<1,2 \mathrm{~m} ; p \geq 24 \mathrm{MPa} ; p \leq 42 \mathrm{MPa} ; t_{p} \leq 250 \mathrm{~min}$} \\
\hline Wyraz wolny & 28,286 & 0,546 & 51,834 & 0,000 & 27,216 & 29,355 & & & & \\
\hline $\begin{array}{l}\text { Współczynnik wpły- } \\
\text { wu odsłonięcie stropu }\end{array}$ & 7,417 & 0,477 & 15,555 & 0,000 & 6,483 & 8,352 & 0,112 & 0,007 & 0,098 & 0,126 \\
\hline $\begin{array}{l}\text { Współczynnik wpły- } \\
\text { wu postępu ściany }\end{array}$ & 0,086 & 0,009 & 9,336 & 0,000 & 0,068 & 0,104 & 0,068 & 0,007 & 0,054 & 0,083 \\
\hline $\begin{array}{l}\text { Współczynnik wpły- } \\
\text { wu wytrzymałość na } \\
\text { ściskanie skał stro- } \\
\text { powych }\end{array}$ & $-0,159$ & 0,008 & $-20,95$ & 0,000 & $-0,174$ & $-0,144$ & $-0,152$ & 0,007 & $-0,166$ & $-0,138$ \\
\hline $\begin{array}{l}\text { Współczynnik wpły- } \\
\text { wu czasu postoju } \\
\text { sekcji }\end{array}$ & 0,030 & 0,001 & 41,595 & 0,000 & 0,028 & 0,031 & 0,303 & 0,007 & 0,289 & 0,317 \\
\hline \multicolumn{11}{|c|}{ Warunek uwzględniania: $d \geq 1,2 \mathrm{~m} ; d<1,4 \mathrm{~m} ; p \geq 24 \mathrm{MPa} ; p \leq 42 \mathrm{MPa} ; t_{p} \leq 250 \mathrm{~min}$} \\
\hline Wyraz wolny & 28,459 & 4,737 & 6,008 & 0,000 & 19,156 & 37,763 & & & & \\
\hline $\begin{array}{l}\text { Współczynnik wpły- } \\
\text { wu odsłonięcie stropu }\end{array}$ & 9,302 & 3,671 & 2,534 & 0,012 & 2,092 & 16,512 & 0,100 & 0,039 & 0,022 & 0,177 \\
\hline $\begin{array}{l}\text { Współczynnik wpły- } \\
\text { wu postępu ściany }\end{array}$ & 0,075 & 0,048 & 1,589 & $\mathbf{0 , 1 1 3}$ & $-0,018$ & 0,169 & 0,062 & 0,039 & $-0,015$ & $\mathbf{0 , 1 4 0}$ \\
\hline $\begin{array}{l}\text { Współczynnik wpły- } \\
\text { wu wytrzymałość na } \\
\text { ściskanie skał stro- } \\
\text { powych }\end{array}$ & $-0,236$ & 0,038 & $-6,139$ & 0,000 & $-0,311$ & $-0,160$ & $-0,243$ & 0,040 & $-0,320$ & $-0,165$ \\
\hline $\begin{array}{l}\text { Współczynnik wpły- } \\
\text { wu czasu postoju } \\
\text { sekcji }\end{array}$ & 0,030 & 0,005 & 5,672 & 0,000 & 0,019 & 0,040 & 0,221 & 0,039 & 0,145 & 0,298 \\
\hline
\end{tabular}


Tabela 4

Ocena istotności modeli

\begin{tabular}{|c|c|c|c|c|c|c|c|c|c|c|c|}
\hline $\begin{array}{c}\text { Zmienna } \\
\text { zależna }\end{array}$ & $\begin{array}{l}\text { Wielo- } \\
\text { krotne } \\
\quad R\end{array}$ & $\begin{array}{l}\text { Wielo- } \\
\text { krotne } \\
R^{2}\end{array}$ & $\begin{array}{c}\text { Skory- } \\
\text { gowane } \\
R^{2}\end{array}$ & $\begin{array}{l}\text { SS } \\
\text { Model }\end{array}$ & $\begin{array}{c}\text { df } \\
\text { Model }\end{array}$ & $\begin{array}{l}\text { MS } \\
\text { Model }\end{array}$ & $\begin{array}{l}\text { SS } \\
\text { Model }\end{array}$ & $\begin{array}{l}\text { Df } \\
\text { Model }\end{array}$ & $\begin{array}{c}\text { MS } \\
\text { Model }\end{array}$ & $\boldsymbol{F}$ & $p$ \\
\hline \multirow{8}{*}{ 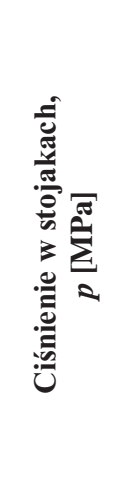 } & \multicolumn{11}{|c|}{$\begin{array}{c}\text { Test SS dla pełnego modelu względem SS dla reszt } \\
\text { Warunek uwzględniania: } d \geq 0,5 \mathrm{~m} ; d<0,6 \mathrm{~m} ; p d \geq 24 \mathrm{MPa} ; p \leq 42 \mathrm{MPa} ; t_{p} \leq 250 \mathrm{~min}\end{array}$} \\
\hline & 0,65 & 0,42 & 0,42 & 242836,6 & 4,0 & 60709,1 & 331315,4 & 28241,0 & 11,73 & 5174,8 & 0,0 \\
\hline & \multicolumn{11}{|c|}{ Warunek uwzględniania: $d \geq 0,6 \mathrm{~m} ; d<0,9 \mathrm{~m} ; p \geq 24 \mathrm{MPa} ; p \leq 42 \mathrm{MPa} ; t_{p} \leq 250 \mathrm{~min}$} \\
\hline & 0,57 & 0,32 & 0,32 & 271432,8 & 4,0 & 67858,2 & 575853,8 & 48471,0 & 11,88 & 5711,8 & 0,0 \\
\hline & \multicolumn{11}{|c|}{ Warunek uwzględniania: $d \geq 0,9 \mathrm{~m} ; d<1,2 \mathrm{~m} ; p \geq 24 \mathrm{MPa} ; p \leq 42 \mathrm{MPa} ; t_{p} \leq 250 \mathrm{~min}$} \\
\hline & 0,36 & 0,13 & 0,13 & 41575,2 & 4,0 & 10393,8 & 283845,8 & 16852,0 & 16,84 & 617,1 & 0,0 \\
\hline & \multicolumn{11}{|c|}{ Warunek uwzględniania: $d \geq 1,2 \mathrm{~m} ; d<1,4 \mathrm{~m} ; p \geq 24 \mathrm{MPa} ; p \leq 42 \mathrm{MPa} ; t_{p} \leq 250 \mathrm{~min}$} \\
\hline & 0,34 & 0,12 & 0,11 & 1330,1 & 4,0 & 332,5 & 9909,4 & 582,0 & 17,03 & 19,5 & 0,0 \\
\hline
\end{tabular}

Dla każdej z analiz wyznaczono model matematyczny pracy sekcji:

- pierwszy przedział odsłonięcia stropu $0,5 \mathrm{~m} \leq d<$ 0,6 m opisano równaniem:

$$
\begin{aligned}
p & =42,2711-20,6182 \cdot d-0,0099 \cdot v \\
& -0,0948 \cdot R_{c}+0,0369 \cdot t_{p} \quad[\mathrm{MPa}]
\end{aligned}
$$

- drugi przedział odsłonięcia stropu 0,6 $\mathrm{m} \leq d<0,9 \mathrm{~m}$ opisano równaniem:

$$
\begin{aligned}
p & =25,7626+8,5766 \cdot d-0,0324 \cdot v \\
& -0,0982 \cdot R_{c}+0,0375 \cdot t_{p} \quad[\mathrm{MPa}]
\end{aligned}
$$

- trzeci przedział odsłonięcia stropu $0,9 \mathrm{~m} \leq d<1,2 \mathrm{~m}$ opisano równaniem:

$$
\begin{array}{r}
p=28,2858+7,4174 \cdot d+0,0857 \cdot v \\
-0,159 \cdot R_{c}+0,0295 \cdot t_{p} \quad[\mathrm{MPa}]
\end{array}
$$

- czwarty przedział odsłonięcia stropu 1,2 m $\leq d<$ 1,4 m opisano równaniem

$$
\begin{aligned}
p & =28,4591+9,3019 \cdot d+0,0755 \cdot v \\
& -0,2357 \cdot R_{c}+0,0296 \cdot t_{p} \quad[\mathrm{MPa}]
\end{aligned}
$$

\section{WYKORZYSTANIE MODELU PRACY SEKCJI DO OKREŚLENIA JEJ WSPÓŁPRACY Z GÓROTWOREM}

Wyznaczone modele matematyczne pracy sekcji obudowy mogą służyć do określenia (tab. 5) podporności roboczej $P_{r}$, momentu obciążenia $M_{Q}$ sekcji obudowy oraz wskaźnika nośności stropu $g$. Otrzyma- ne ze wzorów (11)-(14) prognozowane wartości $p$ możemy wykorzystać w dwojaki sposób:

1) Zakładając, że otrzymana prognozowana wartość $p$ jest ciśnieniem roboczym stojaków sekcji obudowy zmechanizowanej przeliczoną na podporność roboczą $P_{r}$ (tab. 5, kolumna 6), możemy na jej podstawie obliczyć podporność zastępczą $P_{z}$ (wzór (4)), moment podporności $M_{P}$ (wzór (6)). Wykorzystując wzory (7) i (8) wyznaczamy obciążenie wyrobiska eksploatacyjnego $Q$ wraz z momentem obciążenia $M_{Q}$. Otrzymane wyniki wykorzystujemy do wyznaczenia wskaźnika nośności stropu $g$ (wzór (1)). Jak można zauważyć, wraz ze wzrostem wartości podporności roboczej (kolumna 6) wzrastają wartości wskaźnika $g$, które wskazują jednocześnie na bardzo dobrą współpracę sekcji z górotworem. Przyczyną tak dobrego wskaźnika $g$ jest wzrastająca w czasie podporność robocza stojaka i stałe w czasie obciążenie wyrobiska.

2) Zakładając, że otrzymana prognozowana wartość $p$ jest obciążeniem wyrobiska eksploatacyjnego $Q$ zmieniającym się w czasie, możemy ze wzoru (8) obliczyć moment obciążenia $M_{Q}$ (tab. 5, kolumna 7). Podporność zastępczą $P_{z}$ wyznaczamy dla nominalnych wartości podporności roboczej $P_{r}$ i wstępnej $P_{w}$ sekcji ze wzoru 4 . Następnie wyznaczamy moment podporności $M_{p}$ (wzór (6)) i wskaźnik nośności stropu $g$ ze wzoru 1 (tab. 5, kolumna 8). Jak widać, wartości wskaźnika $g$ są ponaddwukrotnie mniejsze, jest to wynikiem stałej wartości podporności roboczej $P_{r}$ i zwiększającego się w czasie obciążenia wyrobiska $Q$. Niemniej jednak otrzymane wartości wskaźnika $g$ gwarantują bardzo dobrą współpracę sekcji obudowy z górotworem. W tym przypadku wraz ze zwiększającym się czasem postoju $t_{p}$ wartość współczynnika zmniejsza się. 
Tabela 5

Przykładowe wartości wskaźnika nośności stropu wyznaczone z modeli matematycznych pracy sekcji obudowy

\begin{tabular}{|c|c|c|c|c|c|c|c|}
\hline$R_{c}[\mathrm{MPa}]$ & $d[\mathrm{~m}]$ & $v$ [m/dobę] & $t_{p}[\mathrm{~min}]$ & $g$ & $P_{r}[\mathrm{MN}]$ & $M_{Q}[\mathrm{MNm}]$ & $g$ \\
\hline 1 & 2 & 3 & 4 & 5 & 6 & 7 & 8 \\
\hline \multirow{12}{*}{30} & \multirow{12}{*}{0,5} & 5 & \multirow{4}{*}{30} & 2,03 & 2,57 & 16,29 & 0,92 \\
\hline & & 10 & & 2,03 & 2,57 & 16,29 & 0,92 \\
\hline & & 15 & & 2,03 & 2,57 & 16,29 & 0,92 \\
\hline & & 20 & & 2,03 & 2,57 & 16,29 & 0,92 \\
\hline & & 5 & \multirow{4}{*}{60} & 2,03 & 2,57 & 16,29 & 0,92 \\
\hline & & 10 & & 2,03 & 2,57 & 16,29 & 0,92 \\
\hline & & 15 & & 2,03 & 2,57 & 16,29 & 0,92 \\
\hline & & 20 & & 2,03 & 2,57 & 16,29 & 0,92 \\
\hline & & 5 & \multirow{4}{*}{250} & 2,07 & 3,07 & 19,46 & 0,84 \\
\hline & & 10 & & 2,07 & 3,07 & 19,46 & 0,84 \\
\hline & & 15 & & 2,07 & 3,07 & 19,46 & 0,84 \\
\hline & & 20 & & 2,07 & 3,06 & 19,40 & 0,84 \\
\hline \multirow{12}{*}{30} & \multirow{12}{*}{0,8} & 5 & \multirow{4}{*}{30} & 2,00 & 2,57 & 17,37 & 0,95 \\
\hline & & 10 & & 2,00 & 2,57 & 17,37 & 0,95 \\
\hline & & 15 & & 2,00 & 2,57 & 17,37 & 0,95 \\
\hline & & 20 & & 2,00 & 2,57 & 17,37 & 0,95 \\
\hline & & 5 & \multirow{4}{*}{60} & 2,00 & 2,57 & 17,37 & 0,95 \\
\hline & & 10 & & 2,00 & 2,57 & 17,37 & 0,95 \\
\hline & & 15 & & 2,00 & 2,57 & 17,37 & 0,95 \\
\hline & & 20 & & 2,00 & 2,57 & 17,37 & 0,95 \\
\hline & & 5 & \multirow{4}{*}{250} & 2,05 & 3,12 & 21,09 & 0,85 \\
\hline & & 10 & & 2,05 & 3,11 & 21,02 & 0,85 \\
\hline & & 15 & & 2,05 & 3,10 & 20,96 & 0,85 \\
\hline & & 20 & & 2,05 & 3,08 & 20,82 & 0,86 \\
\hline \multirow{12}{*}{30} & \multirow{12}{*}{1,1} & 5 & \multirow{4}{*}{30} & 1,97 & 2,65 & 19,03 & 0,95 \\
\hline & & 10 & & 1,98 & 2,68 & 19,24 & 0,95 \\
\hline & & 15 & & 1,98 & 2,72 & 19,53 & 0,94 \\
\hline & & 20 & & 1,98 & 2,75 & 19,75 & 0,93 \\
\hline & & 5 & \multirow{4}{*}{60} & 1,98 & 2,72 & 19,53 & 0,94 \\
\hline & & 10 & & 1,98 & 2,75 & 19,75 & 0,93 \\
\hline & & 15 & & 1,99 & 2,79 & 20,03 & 0,93 \\
\hline & & 20 & & 1,99 & 2,82 & 20,25 & 0,92 \\
\hline & & 5 & \multirow{4}{*}{250} & 2,02 & 3,17 & 22,76 & 0,86 \\
\hline & & 10 & & 2,02 & 3,20 & 22,98 & 0,86 \\
\hline & & 15 & & 2,03 & 3,24 & 23,26 & 0,85 \\
\hline & & 20 & & 2,03 & 3,27 & 23,48 & 0,85 \\
\hline
\end{tabular}


Tabela 5 cd.

\begin{tabular}{|c|c|c|c|c|c|c|c|}
\hline \multirow{12}{*}{30} & \multirow{12}{*}{1,2} & 5 & \multirow{4}{*}{30} & 1,97 & 2,71 & 19,84 & 0,95 \\
\hline & & 10 & & 1,97 & 2,74 & 20,06 & 0,94 \\
\hline & & 15 & & 1,97 & 2,77 & 20,28 & 0,94 \\
\hline & & 20 & & 1,98 & 2,80 & 20,50 & 0,93 \\
\hline & & 5 & \multirow{4}{*}{60} & 1,97 & 2,78 & 20,35 & 0,93 \\
\hline & & 10 & & 1,98 & 2,81 & 20,57 & 0,93 \\
\hline & & 15 & & 1,98 & 2,85 & 20,86 & 0,92 \\
\hline & & 20 & & 1,98 & 2,88 & 21,08 & 0,92 \\
\hline & & 5 & \multirow{4}{*}{250} & 2,02 & 3,24 & 23,72 & 0,86 \\
\hline & & 10 & & 2,02 & 3,27 & 23,94 & 0,86 \\
\hline & & 15 & & 2,02 & 3,30 & 24,16 & 0,85 \\
\hline & & 20 & & 2,02 & 3,33 & 24,32 & 0,85 \\
\hline \multirow{12}{*}{30} & \multirow{12}{*}{1,4} & 5 & \multirow{4}{*}{30} & 1,96 & 2,86 & 21,74 & 0,93 \\
\hline & & 10 & & 1,96 & 2,89 & 21,96 & 0,93 \\
\hline & & 15 & & 1,97 & 2,92 & 22,19 & 0,92 \\
\hline & & 20 & & 1,97 & 2,95 & 22,42 & 0,92 \\
\hline & & 5 & \multirow{4}{*}{60} & 1,97 & 2,93 & 22,27 & 0,92 \\
\hline & & 10 & & 1,97 & 2,96 & 22,50 & 0,91 \\
\hline & & 15 & & 1,97 & 2,99 & 22,72 & 0,91 \\
\hline & & 20 & & 1,97 & 3,03 & 23,03 & 0,90 \\
\hline & & 5 & \multirow{4}{*}{250} & 2,01 & 3,39 & 25,77 & 0,85 \\
\hline & & 10 & & 2,01 & 3,42 & 25,99 & 0,85 \\
\hline & & 15 & & 2,01 & 3,45 & 26,22 & 0,84 \\
\hline & & 20 & & 2,02 & 3,48 & 26,45 & 0,84 \\
\hline
\end{tabular}

Pomimo tak dużej różnicy w otrzymanych wartościach wskaźnika $g$ obydwie drogi jego wyznaczenia są prawidłowe. Różnica leży tylko w ich interpretacji. W przypadku sposobu pierwszego otrzymujemy wskaźnik informujący nas o prawidłowej charakterystyce pracy obudowy dla niezmiennych warunków stropowych. W sposobie drugim wskaźnik informuje nas, że wraz z upływającym czasem wzrasta obciążenie wyrobiska i pogarsza się przez to współpraca sekcji z górotworem.

Na tym etapie prac bezpieczniejsze jest wykorzystywanie wzorów (11)-(14) do prognozowania obciążenia wyrobiska eksploatacyjnego $Q$. Niewykluczone jednak jest, że podczas kolejnych analiz w przypadku następnych ścian eksploatacyjnych i różnych etapów charakterystyki pracy obudowy pierwszy sposób okaże się wartościowy.

\section{PODSUMOWANIE}

W pracy dla opisanych warunków geologiczno-górniczych oraz wyposażenia technicznego rozpatrywanego pola ścianowego wyznaczono wartość minimalnej podporności roboczej sekcji. Uzyskana maksymalna wartość wynosiła $265 \mathrm{kN} / \mathrm{m}^{2}$, a minimalna $95 \mathrm{kN} / \mathrm{m}^{2}$. Według metodologii stosowanej w warunkach polskich kopalń wielkość ta wyniosła $200 \mathrm{kN} / \mathrm{m}^{2}$. Zastosowana w polu ścianowym obudowa zmechanizowana osiąga minimalną podporność roboczą wynoszącą $720 \mathrm{kN} / \mathrm{m}^{2}$.

Na podstawie zebranych danych z programu rejestrującego pracę kompleksu ścianowego dokonano analizy poszczególnych parametrów z uwzględnieniem ograniczeń takich jak maksymalny czas postoju $t_{p}$ przyjęto nie większy niż $250 \mathrm{~min}$, maksymalną 
wartość ciśnienia $42 \mathrm{MPa}$, minimalną wartość ciśnienia $24 \mathrm{MPa}$.

$\mathrm{Z}$ analiz statystycznych wynika, że $41 \%$ wartości odsłonięcia stropu mieści się $\mathrm{w}$ przedziale $0,5-0,6 \mathrm{~m}$.

W czasie postoju sekcji wynoszącego 60 min sekcje były przestawiane w kierunku czoła ściany w celu zabezpieczenia stropu. Takich postojów dla analizowanych danych odnotowano $40 \%$.

Zarejestrowano stosunkowo dużą ilość (38\% przypadków) postojów do $10 \mathrm{~min}$.

Przyrost ciśnienia o $8 \mathrm{MPa}$ obserwuje się dla 57\% odczytanych danych, pozostałe $43 \%$ przypada na przyrost kolejnych $10 \mathrm{MPa}$. Wynika z tego, że rozkład ciśnienia dla poszczególnych jego przedziałów jest podobny.

Po analizie rozkładów poszczególnych parametrów dokonano wyboru kryteriów wykorzystanych przy analizach modelu pracy sekcji $\mathrm{tj}$.:

- czas postoju sekcji $t_{p}$ zawierał się w przedziale od

$0 \mathrm{~min}$ do $250 \mathrm{~min}$,

- odsłonięcie stropu podzielono na przedziały:

- $0,5 \mathrm{~m} \leq d<0,6 \mathrm{~m}$,

- $0,6 \mathrm{~m} \leq d<0,9 \mathrm{~m}$,

- $0,9 \mathrm{~m} \leq d<1,2 \mathrm{~m}$,

- $1,2 \mathrm{~m} \leq d<1,4 \mathrm{~m}$.

Dla przedziałów odsłonięcia stropu $0,5 \mathrm{~m} \leq d<$ $0,6 \mathrm{~m}, 1,2 \mathrm{~m} \leq d<1,4 \mathrm{~m}$ parametrem nieistotnym statystycznie okazał się postęp ściany $v$.

Modele pracy sekcji przy uwzględnieniu wszystkich predyktorów okazały się istotne statystycznie (tab. 4). Uzyskane wielkości skorygowanego $R^{2}$ dla tych modeli o wartościach 0,$42 ; 0,32 ; 12$ i 11 można uznać za zadowalające.

Modele opisano równaniami (wzory (11)-(14)), na podstawie których wyznaczono wartość ciśnienia, które możemy przeliczyć na wartość obciążenia wyrobiska ścianowego $Q$ lub wartość podporności roboczej stojaka sekcji $P_{r}$. Na ich podstawie wyliczono wartości wskaźnika nośności stropu wskazującego w obydwu przypadkach na bardzo dobrą współpracę sekcji z górotworem. Wartości podporności wstępnej i roboczej dla warunków rozpatrywanego pola ścianowego zostały dobrane $\mathrm{z}$ uwzględnieniem sporego ich zapasu.

$\mathrm{Na}$ tym etapie działań z wykorzystaniem zapisów z pracy sekcji obudowy zmechanizowanej w polu ścianowym założenie, iż prognozowana wartość $p$ jest to obciążenie wyrobiska ścianowego $Q$ wydaje się opcją bardziej użyteczną.
Otrzymane wyniki analiz zachęcają do dalszej pracy w kierunku wykorzystania narzędzia pomiarowego, jakim jest kompleks ścianowy. Może on pozwolić nam monitorować górotworu, przez co będzie można lepiej poznać współpracę z górotworem.

\section{Literatura}

[1] Bołoz Ł.: Unique project of single-cutting head longwall shearer used for thin coal seams exploitation, „Archives of Mining Sciences" 2013, 58, 4: 1057-1070.

[2] Korzeniowski W., Herezy Ł. Krauze K., Rak Z., Skrzypkowski K.: Rock mass monitoring based on analysis of powered support response, Wydawnictwa AGH, Kraków 2013.

[3] Barczak T.M.: A retrospective assessment of longwall roof support with a focus on challenging accepted roof support concepts and design premises, 25th International Conference on Ground Control in Mining, Morgantown, West Virginia 2006.

[4] Barczak T.M., Esterhuizen G.S., Ellenberger J., Zahng P.: A first step in developing standing roof support design criteria based on ground reaction data for Pittsburgh seam longwall tailgate support, 27th International conference on ground control in mining, Morgantown, West Virginia 2008.

[5] Biliński A.: Principles of underground working maintenance in longwalls with rockburst hazard, „Archives of Mining Science" 1983, 28, 2: 275-291.

[6] Biliński A.: Metoda doboru obudowy ścianowych wyrobisk wybierkowych i chodnikowych do warunków pola eksploatacyjnego, Prace naukowe - monografie CMG Komag, Gliwice 2005.

[7] Hoyer D.: Early warning of longwall of cavities using LVA software, 12th Coal Operators' Conference, University of Wollongong \& the Australasian Institute of Mining and Metallurgy, Wollongong 2012.

[8] Trueman R., Lyman G., Cocker A.: Longwall roof control through a fundamental understanding of shield-strata interaction, ,Journal of Rock Mechanics Mining Science” 2009, 46: 371-380.

[9] Trueman R., Callan M., Thomas R., Hoyer D.: Quantifying the impact of cover depth and panel width on longwall shieldstrata interactions, 10th Coal Operators Conference, Wollongong 2010.

[10] Trueman R., Thomas R., Hoyer D.: Understanding the causes of roof control problems on a longwall face from shield monitoring data - a case study, 11th Underground Coal Operators Conference, University of Wollongong \& the Australasian Institute of Mining and Metallurgy, Wollongong 2011.

[11] Mahmoud Y.S.: Estimation of bearing capacity of power support in front of longwall face, The Fourth Mining, Petroleum and Metallurgy Conference, Faculty of Engineering, Assiut University, Mining Engineering 1994, 1, 1: 251-255.

[12] Pawlikowski A.: Wpływ podporności wstepnej na podporność stojaków sekcji obudowy zmechanizowanej, „Mining Informatics, Automation and Electrical Engineering” 2016, 4: 72-79.

[13] Płonka M.: Load variation of the set of support in the longwall with roof caving, „Research Reports Mining and Environment" 2009, 1: 41-49.

[14] Prusek S., Płonka A., Walentek A.: Applying the ground reaction curve concept to the assessment of shield support performance in longwall faces, „Arabian Journal of Geosciences” 2016, 9: 1-15. 
[15] Pawlikowski A.: Przyczyny asymetrii podporności stojaków sekcji obudowy zmechanizowanej $w$ świetle badań dołowych, „Maszyny Górnicze” 2017, 1: 45-54.

[16] Szyguła M.: Progress in designing the powered roof support in Poland, „Maszyny Górnicze” 2013, 2: 30-38.

[17] Cemal B., Ergin A.: Design of Supports in Mines, John Wiley \& Sons, New York 1983.

[18] Herezy Ł.: Predicting the vertical convergence of longwall headings basing on the pressure increase factor $\xi$, AGH, Krakow 2017 [praca niepublikowana].

[19] Hussein M.A., Ibrahim A.R., Imbaby S.S.: Load calculations and selection of the powered supports based on rock mass classification and other formulae for Abu-Tartur longwall phosphate mining conditions, „Journal of Engineering Sciences” 2013, 41, 4: 1728-1742.

[20] Herezy Ł.: Relationship between vertical convergence of longwall headings and the pressure increase factor $\xi$ for a powered support section, AGH, Krakow 2017 [praca niepublikowana].
[21] Przegendza G., Przegendza M.: Control and diagnostics systems for mining machines and equipment using a CAN bus, „Szybkobieżne Pojazdy Gąsienicowe” 2007, 2: 1-11.

[22] https://www.statsoft.pl/textbook/stathome.html, 15.09.2017.

dr inż. ŁUKASZ HEREZY

dr hab. inż. WALDEMAR KORZENIOWSKI, prof. nadzw. dr inż. KRZYSZTOF SKRZYPKOWSKI

Katedra Górnictwa Podziemnego Wydziat Górnictwa i Geoinżynierii AGH Akademia Górniczo-Hutnicza im. Stanistawa Staszica w Krakowie al. A. Mickiewicza 30, 30-059 Kraków \{herezy,walkor,skrzypko\}@agh.edu.pl 